Article

\title{
Suggestions of Policy Direction to Improve the Housing Quality in South Korea
}

\author{
Miyeon Park ${ }^{1}$ and Sungho Tae ${ }^{2, *}$ \\ 1 Department of Architectural Engineering, Hanyang University, 55 Hanyangdaehak-ro, Sangnok-gu, \\ Ansan 15588, Korea; bambilol@naver.com \\ 2 School of Architecture \& Architectural Engineering, Hanyang University, 55 Hanyangdaehak-ro, \\ Sangnok-gu, Ansan 15588, Korea \\ * Correspondence: jnb55@hanyang.ac.kr; Tel: +82-31-400-3740, Fax: +82-31-406-7118
}

Academic Editor: Tan Yigitcanlar

Received: 3 March 2016; Accepted: 26 April 2016; Published: 4 May 2016

\begin{abstract}
Following the recent global climate changes, many countries, including developed nations, are announcing greenhouse gas (GHG) reduction targets and are actively participating in reducing GHG. Therefore, the role of the building sector on reducing GHG is being emphasized, and the establishment of policy structures for both making environmentally friendly capacity compulsory and improving the housing quality is being demanded. South Korea is also developing a policy for improving housing quality, but in order to achieve more competitive growth, this must be preceded by an analysis of current policy status within various countries on improving housing quality. This study aims to suggest direction about policies that will improve the housing quality in South Korea. For this, the policies of major countries were able to categorize and compare according to three major categories (performance, function, and aesthetics), and seven factors (safety, durability, cost and maintenance, response to residents' needs, habitability, energy saving, and building design) regarding housing quality. As a result, from the performance aspect, policy directions were suggested for safe housing, the urban environment, regeneration of quality stock, and the usage of existing stock; from the functional aspect, policies for improving housing quality that responds to the aging population and energy saving housing were suggested; from the aesthetic aspect, housing designs that consider the urban environment were suggested.
\end{abstract}

Keywords: housing quality improvement; policy proposal; green building certification system

\section{Introduction}

As global energy use in buildings is sharply increasing, there is rising demand for environmentally friendly performance in buildings as well as contribution to the maintenance and promotion of occupants' health. Many European countries, the United States (US), Canada, and Japan are not only carrying out environmentally friendly certification systems on buildings, they are also conducting studies on indoor finishing materials' environmental friendliness, natural raw materials, and the development of non-toxic building materials. However, South Korea promoted the development of large-scale new towns involving the high-density construction of high-rise housings. In case of Sejong city in South Korea, there was a master plan to construct the over 40 floors of high-rise complex housings and to supply 200,000 households accommodating 500,000 people of Sejong city until 2020 [1,2]. Especially in South Korea's housing market, the "housing supply ratio" which is result dividing the total housing units by the number of households went above $100 \%$ in 2009 , and it reached $103.5 \%$ in 2014 [3]. If the housing supply ratio reaches over 100\%, it means that the number of housing units is more than the households. According to the "real-estate 114" DB, the number of national housings went above 308,337 in 2015 as shown in Figure 1 [4]. The number of national housing sales 
volume is increasing consistently and results in quantitative growth of construction industry in view of housing projects, which is the major business of the construction industry of South Korea.

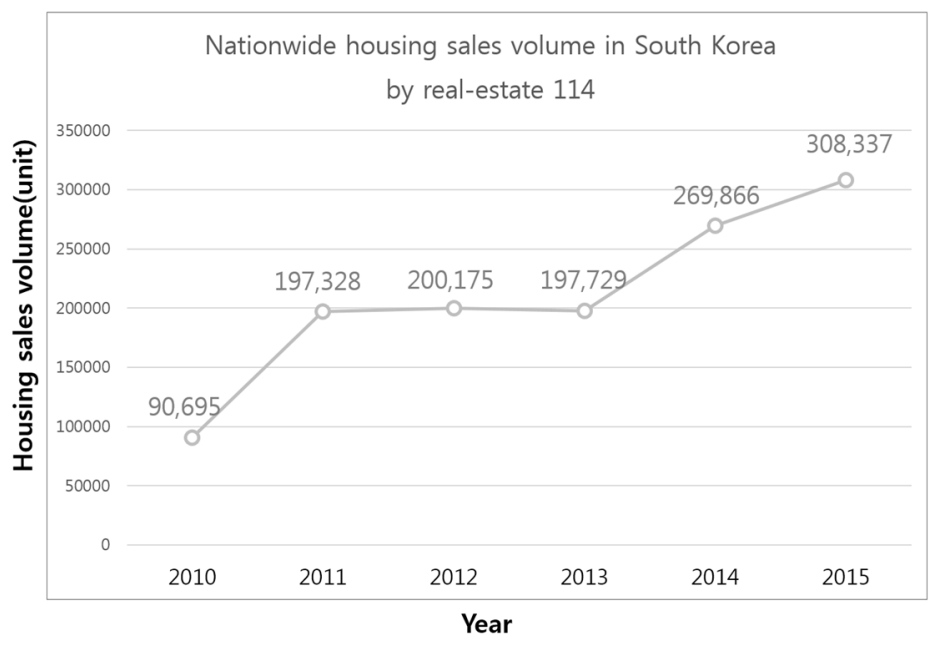

Figure 1. Nationwide housing sales volume in South Korea.

Over the $215 \mathrm{~m}$ high-rise buildings are currently constructed or under construction. High density concrete is used in high-rise buildings. As a result, it is hard to get enough natural draft. The ventilation of high-rise buildings issue which is directly related to human health care is argued by Junsoo Kang. According to him, due to the safety of high-rise buildings, it is hard to ventilate a room. From this, various pollutants and odors are scarcely discharged that people have suffered from headache and stress or diseases such as atopic dermatitis [5]. According to the national research reports, density of carcinogens such as formaldehyde, toluene, or ethylbenzene, appears to be much higher for the high-rise buildings compared to the low-rise buildings [6,7]. Biased toward quantitative growth, we are now arriving at a point where change toward qualitative growth that complements the quantitative growth of construction industry is being demanded [8-10].

From this perspective, the Ministry of Land, Infrastructure, and Transport (MOLIT) has made an announcement that it would become mandatory for new buildings to be zero-energy buildings by 2025, with the purpose of not only reducing GHG, but also improving quality of life. Zero-energy buildings continually save energy and have stable indoor temperatures that can attain the comfort of occupants. In addition, there are also diverse types of research and development in progress such as zero-defect apartment construction (no noise, no eczema and no condensation) [11]. Following the amendments related to improvements in the quality of buildings, health-friendly housing standards have been reinforced such as indoor air quality procurement and the use of health-friendly materials [12]. At the same time, there is an emphasis on energy saving construction that could minimize total energy consumption such as building insulation and usage of highly energy-efficient equipment [13-15].

The South Korean government has developed various policies under the supervision of the Ministry of Land, Infrastructure and Transport (MOLIT) and the Ministry of Environment to facilitate the quality improvement of housing that corresponds to the quantitative growth of buildings; in other words for development of environmentally friendly and habitability performance. Currently, for improving housing quality, the South Korean government has developed 13 housing quality improvement policies such as the Green Standard for Energy and Environmental Design (G-SEED), and the building energy efficiency rating system. Based on such environmentally friendly policies, MOLIT plans to induce low carbon, green growth in the fields of construction that are closely related to the lives and economic activity of people, and to develop related industries while focusing on making people's overall lifestyles more eco-friendly and improve their quality of life [16-18]. 
However, South Korea's policy for improving housing quality has been regressive towards habitability improvement and energy savings. Another problem was a lack of policies for safety and durability related to housing structure due to faulty design and construction as well as the collapsing of housing due to fire. There is demand for assurance in housing security performance and safety. Particularly, establishment of standards in housing safety for high-rise housings considering fire safety and prevention measures was in demand. At the same time, because of the aging society, there is demand for the establishment of a policy base for improving housing quality that is customized to the needs of the elderly.

This study benchmarks the policies from various countries for improving housing quality and attempts to propose the policy directions for improving housing quality in South Korea.

\section{Analysis Method}

The initial concept of categories for housing quality was derived from the three major factors (Structure, Function and Form) in architecture which was argued by Italian structure designer Pier Luigi Nervi. "Structure" is basically a required factor realizing building construction. In the process of applying for a building permit, it is required to satisfy structural design such as earthquake-resistant and building load. Building certification systems are function-oriented. For example, "function" is crucial point to meet green buildings, energy saving buildings and low carbon housings by applying low-E pair glass, renewable energy system, high efficiency equipment, etc. to buildings. Moreover, even if "function" is satisfied, from building to urban scale, it tends to require the approval of occupant's taste such as aesthetic points in the building permit process. The aesthetic aspect is considered to be one of decision points such as preference for tower type apartment rather than flat type apartment in South Korea.

This study selected a total of 10 countries to examine: South Korea, the G8 (Japan, the US, Canada, the United Kingdom, Germany, Russia, Italy, and France), and Spain. The classifications of housing policies were derived from investigating current housing quality improvement schemes and policies of the targeted countries. Especially, a lot of research staffs were involved in the research investigation process and all of them obtained degrees abroad including within the targeted countries of this paper. More importantly, all researchers have diverse research experiences relevant to the housing policies. Through this strategic organic collaboration of research members, it was possible to study the targeted countries' housing policies extensively and have connections with the relevant organizations for consultation. Based on the analysis of policies for housings, considerations of each polices for housing quality could be sorted in aspect of three major categories. The scope achieving the housing quality was classified as the three major categories of performance, function, and aesthetics as shown in Table 1. Performance comprises three middle categories (safety, durability and cost). Function includes two middle categories (response to residents' needs, habitability and energy saving) and Aesthetics involves building design.

Table 1. Categories of housing quality.

\begin{tabular}{ccl}
\hline $\begin{array}{c}\text { Major } \\
\text { Category }\end{array}$ & Middle Category & \\
\hline Performance & $\begin{array}{c}\text { Safety } \\
\text { Durability } \\
\text { Cost }\end{array}$ & $\begin{array}{l}\text { Structural safety, fire safety and prevention, and living safety } \\
\text { Years of durability, maintainability, and defect maintenance } \\
\text { Construction cost, maintenance cost, extension, and alteration costs }\end{array}$ \\
\hline Function & $\begin{array}{c}\text { Response to } \\
\text { residents' needs }\end{array}$ & $\begin{array}{l}\text { Convenience, variability, and consideration for disadvantaged groups } \\
\text { Basic environment (insulation, ventilation, soundproofing, etc.), comfort } \\
\text { (temperature, humidity, etc.), and eco-friendliness (LCCO, biotope, etc.) }\end{array}$ \\
\hline Aesthetics & Building Design & Exterior appearance, shape, color, and material quality \\
\hline
\end{tabular}


Most of all, the three major housing quality categories of performance, function, and aesthetics were further analyzed through seven detailed categories including safety, durability, cost, response to residents' needs, habitability, energy saving, and building design. Each country's measures and policies were separately examined and then analyzed through the housing quality categories.

\section{Analysis of Each Country's Policies}

\subsection{Policy Status for Housing Quality in South Korea}

Most housing quality housing policies of South Korea aim to improve fragmentary item of housing quality. Otherwise, both "Apartment housing performance grading system" and "Green Standard for Standard for Energy and Environmental Design (G-SEED)" are conducting the comprehensive assessment of housing quality and environmental performance. In addition, past policy, which is about housing quality improvement, gave weight to enhancing habitability, meanwhile, due to the severity of the global environmental problem, demand for energy-saving buildings became importance, recently. Especially, the "apartment housing performance grading system" is mentionable as the policy that comprehensively assess habitability, energy-saving, safety and durability of the building.

Table 2 shows South Korea's current status regarding housing quality improvement policies. From the performance aspect, safety, durability, cost, and maintenance all carried almost equal weight, but many policies were biased toward the functional aspect as shown in Figure 2. Particularly in terms of housing quality improvement, G-SEED is being operated by assessing the building's eco-friendly elements from functional aspect and issuing certificates [19]. The Building Act and the Housing Act previously had overlap in terms of eco-friendly buildings and their certification criteria. Now, the Green Building Certification Criteria and the Housing Performance Rating System, which were sub-regulations in each act, were combined as the G-SEED. The Housing Performance Rating System was separated in 2014 and is currently operating to allow consumers to examine housing performance beforehand.

Table 2. Policy status for quality of housing in South Korea.

\begin{tabular}{|c|c|c|c|c|c|c|c|c|}
\hline \multirow{3}{*}{ No. } & \multirow{3}{*}{ Policy } & \multicolumn{7}{|c|}{ Housing Quality ${ }^{(1)}$} \\
\hline & & \multicolumn{3}{|c|}{ Performance } & \multicolumn{3}{|c|}{ Function } & \multirow{2}{*}{$\begin{array}{c}\text { Aesthetics } \\
\text { Building } \\
\text { Design }\end{array}$} \\
\hline & & Safety & Durability & $\operatorname{Cost}^{(2)}$ & Response $^{(3)}$ & Habitability & $\begin{array}{l}\text { Energy } \\
\text { Saving }\end{array}$ & \\
\hline 1 & $\begin{array}{l}\text { Policy on the air } \\
\text { quality of new } \\
\text { apartment housing }\end{array}$ & & & & & $\bullet$ & & \\
\hline 2 & $\begin{array}{l}\text { high-speed } \\
\text { telecommunication } \\
\text { building certification } \\
\text { system }\end{array}$ & & & & $\bullet$ & & & \\
\hline 3 & $\begin{array}{l}\text { Building Energy } \\
\text { Efficiency } \\
\text { Certification System }\end{array}$ & & & $\bigcirc$ & & & $\bullet$ & \\
\hline 4 & $\begin{array}{l}\text { Apartment housing } \\
\text { Remodeling } \\
\text { Structural } \\
\text { Specifications }\end{array}$ & & $\bullet$ & $\bigcirc$ & ○ & $\Delta$ & $\Delta$ & \\
\hline 5 & $\begin{array}{l}\text { Green Standard for } \\
\text { Energy and } \\
\text { Environmental Design }\end{array}$ & $\Delta$ & 0 & & $\bigcirc$ & $\bullet$ & $\bullet$ & \\
\hline 6 & $\begin{array}{l}\text { Healthy Building } \\
\text { Material }\end{array}$ & & & & & - & & \\
\hline
\end{tabular}


Table 2. Cont.

\begin{tabular}{|c|c|c|c|c|c|c|c|c|}
\hline \multirow{3}{*}{ No. } & \multirow{3}{*}{ Policy } & \multicolumn{7}{|c|}{ Housing Quality ${ }^{(\mathbf{1})}$} \\
\hline & & \multicolumn{3}{|c|}{ Performance } & \multicolumn{3}{|c|}{ Function } & \multirow{2}{*}{$\begin{array}{c}\text { Aesthetics } \\
\text { Building } \\
\text { Design }\end{array}$} \\
\hline & & Safety & Durability & $\operatorname{Cost}^{(2)}$ & Response ${ }^{(3)}$ & Habitability & $\begin{array}{l}\text { Energy } \\
\text { Saving }\end{array}$ & \\
\hline 7 & $\begin{array}{l}\text { Recognition and } \\
\text { administration of } \\
\text { structure Floor Impact } \\
\text { Sound Insulation for } \\
\text { Apartment Houses }\end{array}$ & & & & & $\bullet$ & & \\
\hline 8 & $\begin{array}{l}\text { Apartment housing } \\
\text { performance grading } \\
\text { system }\end{array}$ & $\bullet$ & $\Delta$ & & 0 & $\bullet$ & $\Delta$ & \\
\hline 9 & $\begin{array}{l}\text { Intelligent Building } \\
\text { System }\end{array}$ & & & & $\bullet$ & • & & \\
\hline 10 & $\begin{array}{l}\text { Home network } \\
\text { apartment building } \\
\text { certification system }\end{array}$ & & & & $\bullet$ & & & \\
\hline 11 & Barrier Free & 0 & & & $\bullet$ & & & \\
\hline 12 & $\begin{array}{l}\text { GD(Good Design) } \\
\text { mark system }\end{array}$ & & & & & & & $\bullet$ \\
\hline 13 & $\begin{array}{l}\text { Seoul Architectural } \\
\text { Design-Review } \\
\text { System }\end{array}$ & & & & & & & $\bullet$ \\
\hline \multirow{2}{*}{$\begin{array}{l}\text { Total } \\
\text { score }\end{array}$} & Middle category score & 3 & 3 & 2 & 7 & 7 & 4 & 2 \\
\hline & Major category score & & 8 & & & 18 & & 2 \\
\hline
\end{tabular}

(1) Related with housing quality: $\bullet$ (relevant high), $\bigcirc$ (normal), $\Delta$ (less relevant); ${ }^{(2)}$ Cost and maintenance;

(3) Response to residents' needs

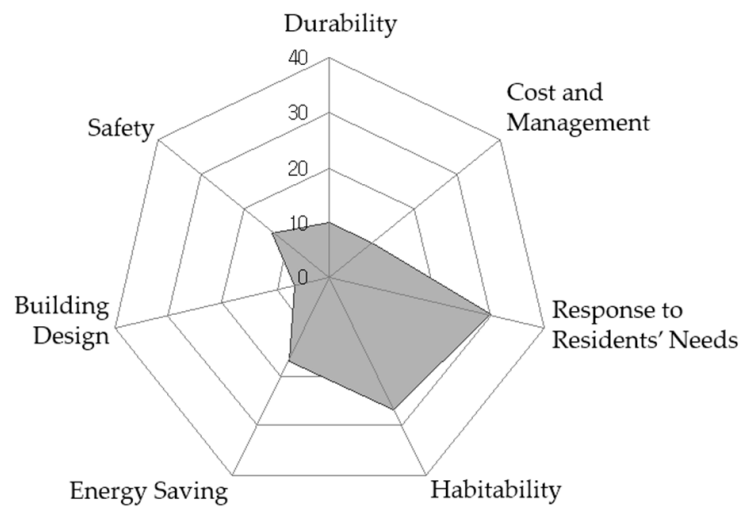

Figure 2. Radar chart of housing quality improvement policy feature in South Korea.

Including the G-SEED, such policies on housing quality improvement in South Korea should be considered with systematic performance complements. There is a lack of housing quality legislation for high-rises despite the current trend in housing becoming higher in height due to rising land-use efficiency in the construction industry. Therefore, there is demand for criteria that assesses the safety and durability of housing structures and disaster prevention that is specific to high-rises from the perspective of performance.

From a functional aspect, South Korea's G-SEED was carrying out comprehensive assessments that included safety and durability. However, there was more weight on considering function. Even within function, it was found that there was bias towards habitability and energy saving. Regarding habitability and energy saving within the function category, the G-SEED was mostly comprised of assessment categories such as the interior air quality of the habitation and the use of 
green construction material. It also was used for policy on the air quality of new apartments, sick house syndrome under habitability within the function category, and the formation of a comfortable interior environment via assessing indoor air quality and pollution. This seems to be the result of a recent rise in consideration for the elderly and the disabled as well as interest in green construction. Meanwhile, only the Building Energy Efficiency Certification System primarily dealt with energy saving by providing accurate information on energy consumption in buildings.

For policies on building design from the aesthetical aspect, there is the Good Design mark system and the Seoul Architectural Design-Review System.

\subsection{Policy Status for Housing Quality in Japan}

As summarized in Table 3, Japan's policies to improve housing quality were evenly distributed across the aspects of performance and function. Particularly, compared to other countries, there were more tendencies for many policies to be distributed on safety within the category of performance as shown in Figure 3. Regarding safety policies, there was legislation promoting the improvement of earthquake resistance construction through earthquake-proofing diagnosis, advice, and guidance on maintenance, and subsidization. In addition, the Model Anticrime Mansion Certification System, the Century Housing System, the Safe Interior Material Certification System, the Standard Value mark considering the wallpaper product standard, and the High-rise Building Performance Evaluation System were investigated [20-22]. Meanwhile, Japan's Housing Quality Assurance Act dealt evenly with the performance and functional aspects.

Table 3. Policy status for quality of housing in Japan.

\begin{tabular}{|c|c|c|c|c|c|c|c|c|}
\hline \multirow{3}{*}{ No. } & \multirow{3}{*}{ Policy } & \multicolumn{7}{|c|}{ Housing Quality ${ }^{(1)}$} \\
\hline & & \multicolumn{3}{|c|}{ Performance } & \multicolumn{3}{|c|}{ Function } & \multirow{2}{*}{$\begin{array}{c}\text { Aesthetics } \\
\text { Building } \\
\text { Design }\end{array}$} \\
\hline & & Safety & Durability & $\operatorname{Cost}^{(2)}$ & Response ${ }^{(3)}$ & Habitability & $\begin{array}{l}\text { Energy } \\
\text { Saving }\end{array}$ & \\
\hline 1 & $\begin{array}{l}\text { Housing quality } \\
\text { assurance act }\end{array}$ & $\bigcirc$ & $\bigcirc$ & $\bigcirc$ & 0 & O & 0 & \\
\hline 2 & $\begin{array}{l}\text { Legislation promoting } \\
\text { improvement of } \\
\text { earthquake-resistant } \\
\text { construction }\end{array}$ & $\bullet$ & & 0 & & & & \\
\hline 3 & $\begin{array}{l}\text { A system of a quality } \\
\text { rental housing for the } \\
\text { elderly }\end{array}$ & & & & $\bullet$ & & & \\
\hline 4 & $\begin{array}{l}\text { Environment and } \\
\text { energy friendly } \\
\text { building mark }\end{array}$ & & & & & & $\bullet$ & \\
\hline 5 & $\begin{array}{l}\text { Next-generation home } \\
\text { energy systems }\end{array}$ & & & & & & $\bullet$ & \\
\hline 6 & $\begin{array}{l}\text { CASBEE } \\
\text { (Comprehensive } \\
\text { Assessment System } \\
\text { for Building } \\
\text { Environmental } \\
\text { Efficiency) }\end{array}$ & O & O & $\bigcirc$ & 0 & $\bullet$ & $\bullet$ & \\
\hline 7 & $\begin{array}{l}\text { Certification of model } \\
\text { crime-resistant } \\
\text { apartment buildings }\end{array}$ & $\bullet$ & & & & & & \\
\hline 8 & $\begin{array}{l}\text { Environmentally } \\
\text { symbiotic housing } \\
\text { model projects }\end{array}$ & & 0 & $\bigcirc$ & 0 & 0 & 0 & \\
\hline 9 & $\begin{array}{l}\text { CENTURY housing } \\
\text { system }\end{array}$ & O & 0 & $\bigcirc$ & 0 & 0 & & \\
\hline
\end{tabular}


Table 3. Cont.

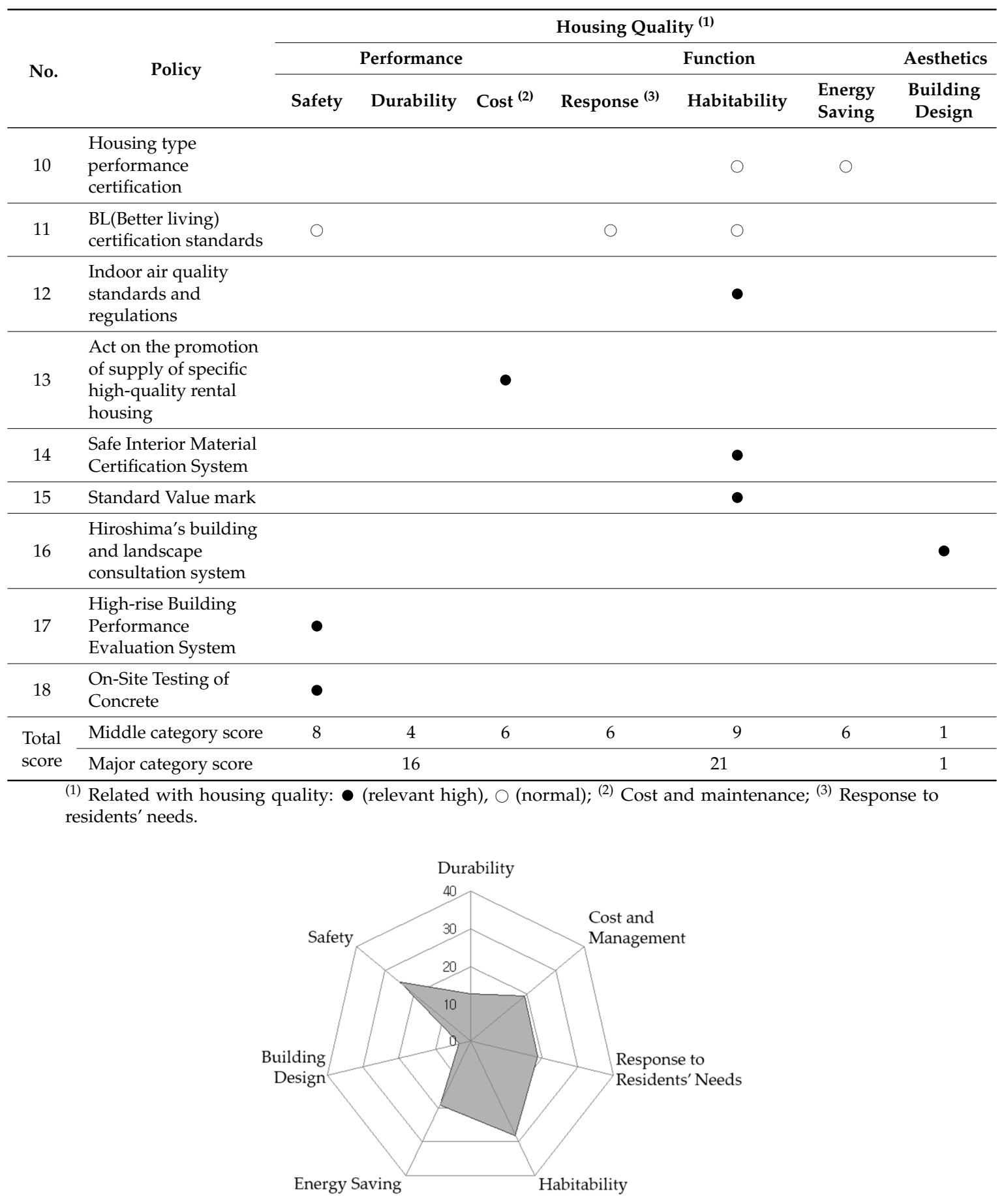

Figure 3. Radar chart of housing quality improvement policy feature in Japan.

For policies on the performance aspect of housing, there was legislation on the promotion of earthquake-resistance improvement for buildings, the Model Anticrime Mansion Certification System, the Century Housing System, the Safe Interior Material Certification System, Standard Value mark, and the High-rise Building Performance Certification System. These are systems that do not exist in South Korea, and most of them have been found to emphasize safety and durability with regard to the performance category [23]. Particularly, the High-rise Building Performance Evaluation System is a program that assesses the structural safety of high-rises higher than 60 meters. 
From a functional aspect, most policies are related to habitability. Among the policies related to improving habitability, there was the Safe Interior Material Certification System. Meanwhile, Japan's Comprehensive Assessment System for Building Environmental Efficiency (CASBEE), which was similar to South Korea's G-SEED was studied. The CASBEE was assessing Life Cycle $\mathrm{CO}_{2}$ and habitability on the building's environmental load [24,25].

For policies on building design under the category of aesthetics, there was Hiroshima's building and landscape consultation system. This has been found to be similar to the Seoul Architectural Design-Review System that is under the supervision of the city of Seoul [26].

\subsection{Policy Status for Housing Quality in the US}

The US's policies for improving housing quality totaled 15, and as shown in Table 4 and Figure 4, there is an even distribution across the performance and functional aspects.

Table 4. Policy status for quality of housing in US.

\begin{tabular}{|c|c|c|c|c|c|c|c|c|}
\hline \multirow{3}{*}{ No. } & \multirow{3}{*}{ Policy } & \multicolumn{7}{|c|}{ Housing Quality ${ }^{(1)}$} \\
\hline & & \multicolumn{2}{|c|}{ Performance } & \multicolumn{4}{|c|}{ Function } & \multirow{2}{*}{$\begin{array}{c}\text { Aesthetics } \\
\text { Building } \\
\text { Design }\end{array}$} \\
\hline & & Safety & Durability & Cost ${ }^{(2)}$ & Response ${ }^{(3)}$ & Habitability & $\begin{array}{l}\text { Energy } \\
\text { Saving }\end{array}$ & \\
\hline 1 & How Program & $\bullet$ & $\Delta$ & & 0 & $\bullet$ & $\Delta$ & \\
\hline 2 & $\begin{array}{l}\text { FHA (Fair } \\
\text { Housing Act) }\end{array}$ & & & $\bullet$ & 0 & & & \\
\hline 3 & $\begin{array}{l}\text { FHAA (Fair } \\
\text { Housing } \\
\text { Amendments Act) }\end{array}$ & & & & $\bullet$ & & & \\
\hline 4 & $\begin{array}{l}\text { HERS (Home } \\
\text { Energy Rater } \\
\text { assesses the energy } \\
\text { efficiency of a home) }\end{array}$ & & & & & & • & \\
\hline 5 & $\begin{array}{l}\text { Energy Star } \\
\text { Home/Building } \\
\text { Program }\end{array}$ & & & & & & $\bullet$ & \\
\hline 6 & $\begin{array}{l}\text { EEM (Energy } \\
\text { Efficient Mortgage) }\end{array}$ & & & 0 & & O & $\bullet$ & \\
\hline 7 & $\begin{array}{l}\text { LEED (Leadership } \\
\text { in Energy and } \\
\text { Environmental } \\
\text { Design) }\end{array}$ & $\Delta$ & $\Delta$ & 0 & 0 & $\bullet$ & $\bullet$ & \\
\hline 8 & $\begin{array}{l}\text { Built GreenTM } \\
\text { Rating System }\end{array}$ & & & 0 & & $\bullet$ & • & \\
\hline 9 & $\begin{array}{l}\text { The American Lung } \\
\text { Association Health } \\
\text { House Program }\end{array}$ & & & ○ & & $\bullet$ & $\bullet$ & \\
\hline 10 & $\begin{array}{l}\text { Green Points } \\
\text { Program }\end{array}$ & & & 0 & & $\bullet$ & $\bullet$ & \\
\hline 11 & $\begin{array}{l}\text { Community } \\
\text { development } \\
\text { support }\end{array}$ & & & $\bullet$ & & & & \\
\hline 12 & $\begin{array}{l}\text { Home improvement } \\
\text { loan }\end{array}$ & & & • & & & & \\
\hline 13 & $\begin{array}{l}\text { Special Evaluation } \\
\text { Assistance for Rural } \\
\text { Communities and } \\
\text { Households }\end{array}$ & & & • & & & & \\
\hline
\end{tabular}


Table 4. Cont.

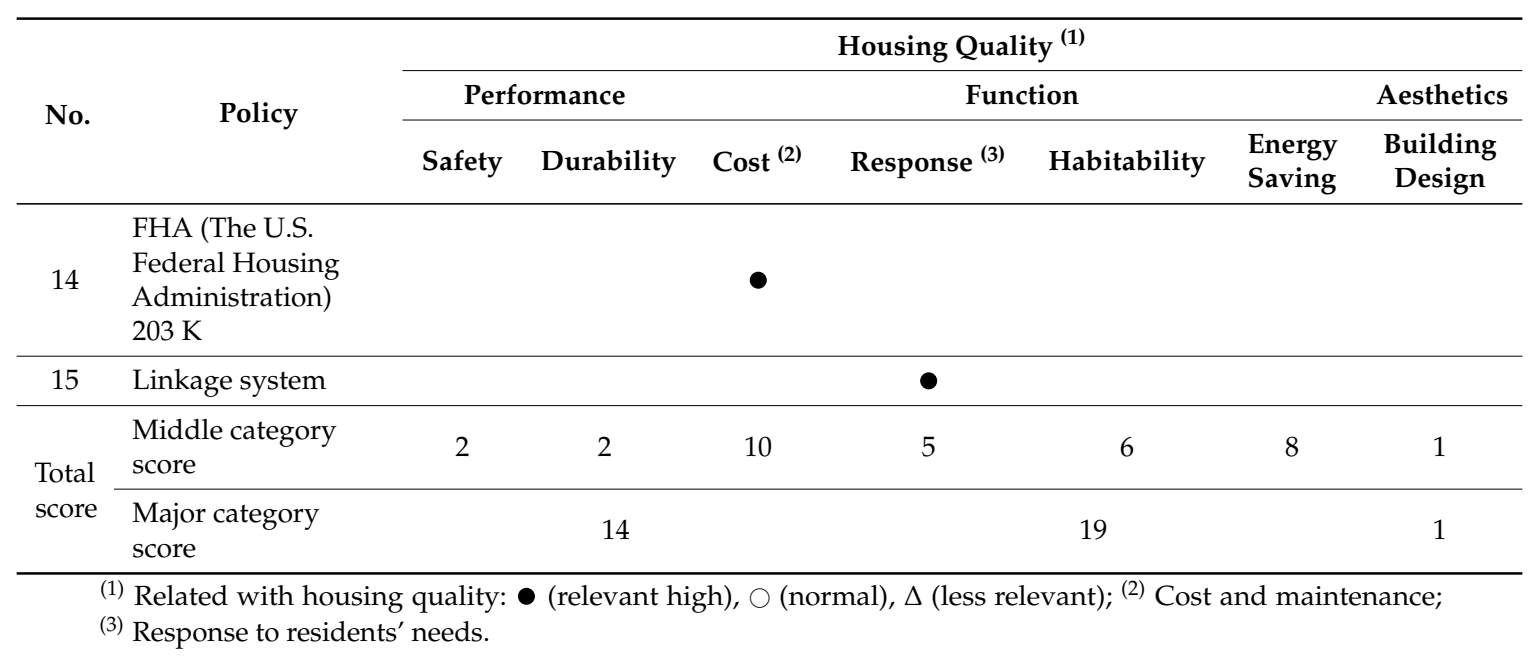

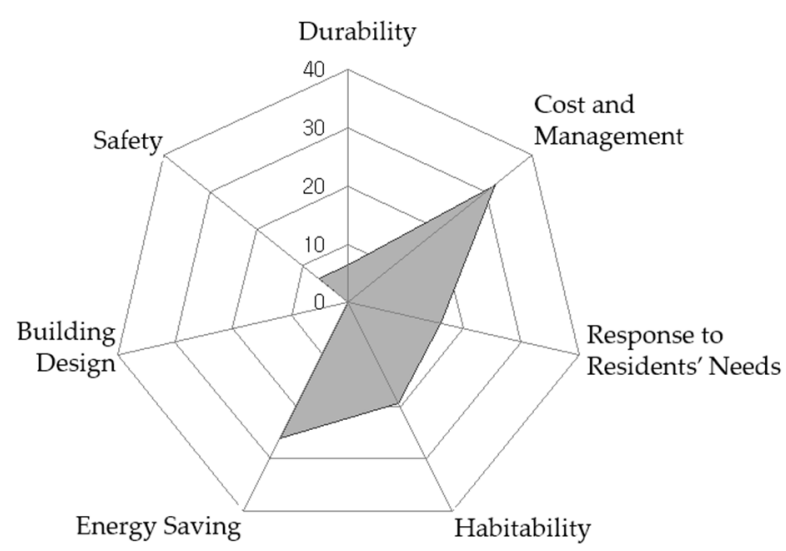

Figure 4. Radar chart of housing quality improvement policy feature in U.S.

Regarding the performance aspects, the weight on policies for cost and maintenance was high among other categories. This was shown to be the result of US housing improvement programs for low income people, the disabled, and the elderly. Meanwhile, the HOW Program was studied as the US's housing performance assessment rating system, made based on the UK's NHBC [27,28]. Similar systems were France's Qualitel and Japan's Housing Quality Assurance Act. Whereas South Korea's Housing Performance Rating System is a requirement by law, the US's HOW Program was being run through self-regulation by those in the industry $[29,30]$.

Regarding the functional aspects, there was a tendency for even distribution across the responses to the needs of residents, habitability, and energy savings categories. Meanwhile, it was analyzed that the LEED, Built Green TM Rating System, and the Green Points Program evenly assess the performance aspects and functional aspects [31-34].

\subsection{Policy Status for Housing Quality in Canada}

Table 5 and Figure 5 show Canada's policies on improving housing quality, and also show a tendency for many policies to be distributed in the functional aspect. There was a high proportion of policies on habitability and energy saving. This was analyzed by showing a similar trend to the housing policies of European countries that emphasize the importance of energy savings in building. However, when compared with the functional aspect, there was a relatively low proportion of policies on the performance aspect, and it was found that the Home Warranty Program, similar to South Korea's Housing Performance Rating System, was being run [35-37]. 
Table 5. Policy status for quality of housing in Canada.

\begin{tabular}{|c|c|c|c|c|c|c|c|c|}
\hline \multirow{3}{*}{ No. } & \multirow{3}{*}{ Policy } & \multicolumn{7}{|c|}{ Housing Quality ${ }^{(1)}$} \\
\hline & & \multicolumn{3}{|c|}{ Performance } & \multicolumn{3}{|c|}{ Function } & \multirow{2}{*}{$\begin{array}{c}\text { Aesthetics } \\
\text { Building } \\
\text { Design }\end{array}$} \\
\hline & & Safety & Durability & Cost ${ }^{(2)}$ & Response ${ }^{(3)}$ & Habitability & $\begin{array}{l}\text { Energy } \\
\text { Saving }\end{array}$ & \\
\hline 1 & $\begin{array}{l}\text { Home Warranty } \\
\text { Program }\end{array}$ & $\bigcirc$ & $\bigcirc$ & $\bigcirc$ & $\bigcirc$ & $\bigcirc$ & 0 & \\
\hline 2 & $\begin{array}{l}\text { R-2000 standard, } \\
\text { C-2000 standard }\end{array}$ & & & 0 & & 0 & O & \\
\hline 3 & $\begin{array}{l}\text { Super } E^{T M} \text { House } \\
\text { Program }\end{array}$ & & & 0 & O & O & 0 & \\
\hline 4 & EnviroHome & & & & 0 & $\bigcirc$ & 0 & \\
\hline 5 & Novoclimat & $\bigcirc$ & & & & 0 & $\bullet$ & \\
\hline 6 & $\begin{array}{l}\text { EnerGuide for } \\
\text { Houses(EGNH) }\end{array}$ & & & & & 0 & $\bullet$ & \\
\hline 7 & $\begin{array}{l}\text { Built GreenTM } \\
\text { Alberta }\end{array}$ & & 0 & $\bigcirc$ & & $\bigcirc$ & $\bullet$ & \\
\hline 8 & $\begin{array}{l}\text { Energy Star } \\
\text { Program }\end{array}$ & & & & & & $\bullet$ & \\
\hline 9 & $\begin{array}{l}\text { Power Smart in } \\
\text { British Columbia }\end{array}$ & & & & & & $\bullet$ & \\
\hline 10 & $\begin{array}{l}\text { Power Smart in } \\
\text { Manitoba }\end{array}$ & & & & & & $\bullet$ & \\
\hline 11 & $\begin{array}{l}\text { Building Canada } \\
\text { Program }\end{array}$ & & & & & & $\bullet$ & \\
\hline 12 & Green Globes & & & & & 0 & $\bullet$ & \\
\hline 13 & $\begin{array}{l}\text { “Net Zero Energy } \\
\text { Home" Proposal }\end{array}$ & O & & & & $\bullet$ & & \\
\hline 14 & $\begin{array}{l}\text { CBIP (Commercial } \\
\text { Building Incentive } \\
\text { Program) }\end{array}$ & & & & & $\bullet$ & & \\
\hline 15 & $\begin{array}{l}\text { Exposure } \\
\text { Guideline for } \\
\text { Residential Indoor } \\
\text { Air Quality }\end{array}$ & & & & & $\bullet$ & & \\
\hline 16 & $\begin{array}{l}\text { ECP (The } \\
\text { Environmental } \\
\text { Choice Program) }\end{array}$ & $\bigcirc$ & & & & $\bullet$ & & \\
\hline \multirow{2}{*}{$\begin{array}{l}\text { Total } \\
\text { score }\end{array}$} & $\begin{array}{l}\text { Middle category } \\
\text { score }\end{array}$ & 4 & 2 & 4 & 3 & 12 & 12 & - \\
\hline & $\begin{array}{l}\text { Major category } \\
\text { score }\end{array}$ & & 10 & & & 27 & & - \\
\hline
\end{tabular}

(1) Related with housing quality: • (relevant high), $\bigcirc$ (normal), $\Delta$ (less relevant); ${ }^{(2)}$ Cost and maintenance;

(3) Response to residents' needs. 


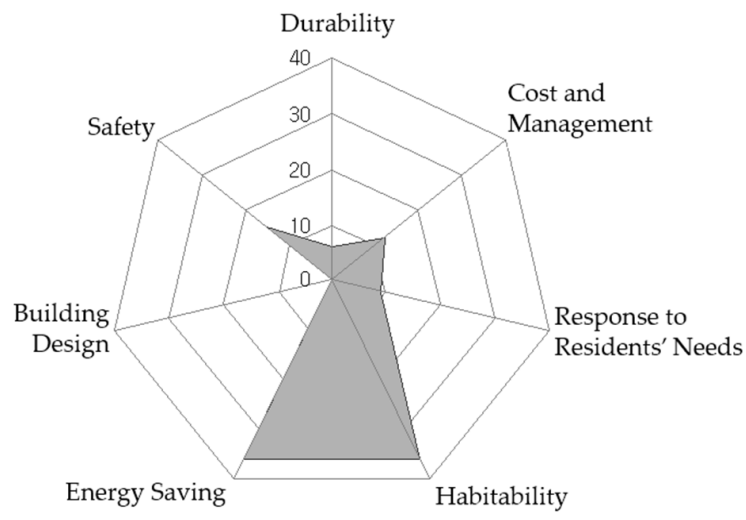

Figure 5. Radar chart of housing quality improvement policy feature in Canada.

In the functional aspect, there were many policies regarding habitability and energy savings. Particularly, there was a deeper association with energy savings than with habitability. For an independent system, the Net Zero Energy Home Proposal was analyzed. This system was examined as attempting to reflect the concept of Net-zero Energy into housing design by the year 2030 by applying renewable energy and technologies of efficient energy use [38-40].

Policies in the aesthetic category were not studied.

\subsection{Policy Status for Housing Quality in the UK}

The UK's policies on improving housing quality were evenly distributed across the performance and functional aspects. Especially, as shown in Table 6 and Figure 6, many policies were distributed on cost and maintenance under the performance aspect, and on habitability under the functional aspect [41,42].

Table 6. Policy status for quality of housing in England.

\begin{tabular}{|c|c|c|c|c|c|c|c|c|}
\hline \multirow{3}{*}{ No. } & \multirow{3}{*}{ Policy } & \multicolumn{7}{|c|}{ Housing Quality ${ }^{(1)}$} \\
\hline & & \multicolumn{3}{|c|}{ Performance } & \multicolumn{3}{|c|}{ Function } & \multirow{2}{*}{$\begin{array}{c}\text { Aesthetics } \\
\text { Building } \\
\text { Design }\end{array}$} \\
\hline & & Safety & Durability & Cost ${ }^{(2)}$ & Response ${ }^{(3)}$ & Habitability & $\begin{array}{l}\text { Energy } \\
\text { Saving }\end{array}$ & \\
\hline 1 & $\begin{array}{l}\text { Home Warranty } \\
\text { System }\end{array}$ & $\bullet$ & $\Delta$ & $\Delta$ & 0 & $\bullet$ & 0 & \\
\hline 2 & $\begin{array}{l}\text { HEES (Home } \\
\text { Energy Efficiency } \\
\text { Scheme) }\end{array}$ & & & & & 0 & $\bullet$ & \\
\hline 3 & $\begin{array}{l}\text { SAP \& SAP 80+ } \\
\text { initiative (Standard } \\
\text { Assessment } \\
\text { Procedure) }\end{array}$ & & & & & 0 & $\bullet$ & \\
\hline 4 & $\begin{array}{l}\text { General } \\
\text { Improvement Area, } \\
\text { Housing Acting } \\
\text { Area }\end{array}$ & & & $\bullet$ & 0 & & & \\
\hline 5 & $\begin{array}{l}\text { The Low Carbon } \\
\text { Building Program }\end{array}$ & & & & & & $\bullet$ & \\
\hline 6 & $\begin{array}{l}\text { Millennium } \\
\text { Communities } \\
\text { Program }\end{array}$ & & 0 & & & 0 & $\bullet$ & \\
\hline 7 & Improvement Grant & & & • & $\bigcirc$ & $\bigcirc$ & & \\
\hline 8 & Intermediate Grant & & & $\bullet$ & & 0 & & \\
\hline 9 & Special Grant & & & - & & 0 & & \\
\hline
\end{tabular}


Table 6. Cont.

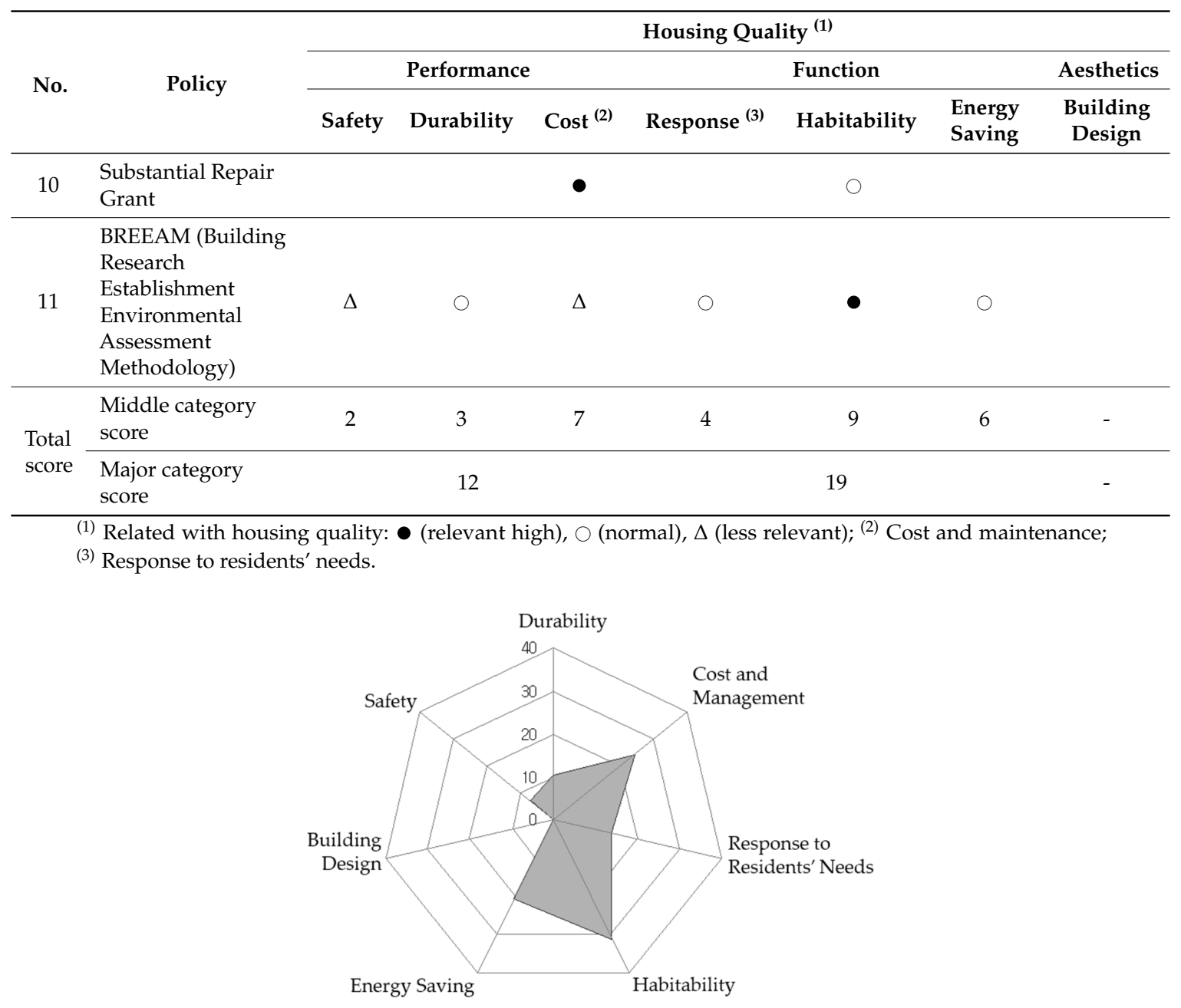

Figure 6. Radar chart of housing quality improvement policy feature in U.K.

In the performance aspect, there was a higher proportion of policies regarding cost and maintenance, seemingly due to the background of active operations of housing improvement support programs for low income people, the disabled, and the elderly. This trend was shown to be similar to the results in the US. Meanwhile, the UK has the How Warranty System that is similar to South Korea's Housing Performance Rating System, and it was being run by the NHBC (National House-Building Council). Warranty services were being done through an independent civil system, which was similar to France's Quality system in that it covers the defects through insurance [43-45].

In the functional aspect, there was great importance placed on habitability and energy savings. In the case of policies for energy savings, since there was demand for performance improvement within general environments such as insulation, ventilation, and soundproofing, there was a tendency for overlap in most policies regarding habitability assessment and energy savings assessment. Various UK policies for energy savings in buildings were studied, among them the Low Carbon Building Program was examined as a concrete and assertive policy for $\mathrm{CO}_{2}$ emissions reduction in buildings. Meanwhile, the BREEAM (Building Research Establishment Environment Assessment Method) was studied as a system that considers everything under the functional aspect: response to residents' needs, habitability, and energy savings. BREEAM assesses on five kinds of usage such as offices, housing, schools, public facilities, and private facilities [46-48].

It was found that there was no policy related to the aesthetic aspect. 


\subsection{Policy Status for Housing Quality in Germany}

In the case of Germany's policies on improving housing quality, as shown in Table 7 and Figure 7 , there was more weight on consideration for the functional aspect than the performance aspect, and particularly, there was a high proportion of policies regarding habitability under the functional aspect.

Table 7. Policy status for quality of housing in Germany.

\begin{tabular}{|c|c|c|c|c|c|c|c|c|}
\hline \multirow{3}{*}{ No. } & \multirow{3}{*}{ Policy } & \multicolumn{7}{|c|}{ Housing Quality ${ }^{(1)}$} \\
\hline & & \multicolumn{3}{|c|}{ Performance } & \multicolumn{3}{|c|}{ Function } & \multirow{2}{*}{$\begin{array}{c}\text { Aesthetics } \\
\text { Building } \\
\text { Design }\end{array}$} \\
\hline & & Safety & Durability & Cost ${ }^{(2)}$ & Response $^{(3)}$ & Habitability & $\begin{array}{l}\text { Energy } \\
\text { Saving }\end{array}$ & \\
\hline 1 & $\begin{array}{l}\text { EMICODE (indicate } \\
\text { low emission } \\
\text { products for } \\
\text { flooring installation } \\
\text { and building } \\
\text { materials) }\end{array}$ & & & & & $\bullet$ & & \\
\hline 2 & $\begin{array}{l}\text { Eurofins Indoor Air } \\
\text { Comfort (IAC) }\end{array}$ & & & & & $\bullet$ & & \\
\hline 3 & $\begin{array}{l}\text { Flexible Residential } \\
\text { Housing EE } \\
\text { Program in } \\
\text { Germany (KfW) }\end{array}$ & & & $\bullet$ & & $\bullet$ & 0 & \\
\hline 4 & $\begin{array}{l}\text { Blue Angel } \\
\text { (Ecolabel index) }\end{array}$ & & & & & $\bullet$ & & \\
\hline 5 & $\begin{array}{l}\text { Germany } \\
\text { Passivhaus } \\
\text { certification }\end{array}$ & & & & & & $\bullet$ & \\
\hline \multirow{2}{*}{$\begin{array}{l}\text { Total } \\
\text { score }\end{array}$} & $\begin{array}{l}\text { Middle category } \\
\text { score }\end{array}$ & - & - & 1 & - & 4 & 2 & - \\
\hline & $\begin{array}{l}\text { Major category } \\
\text { score }\end{array}$ & & 1 & & & 6 & & - \\
\hline
\end{tabular}

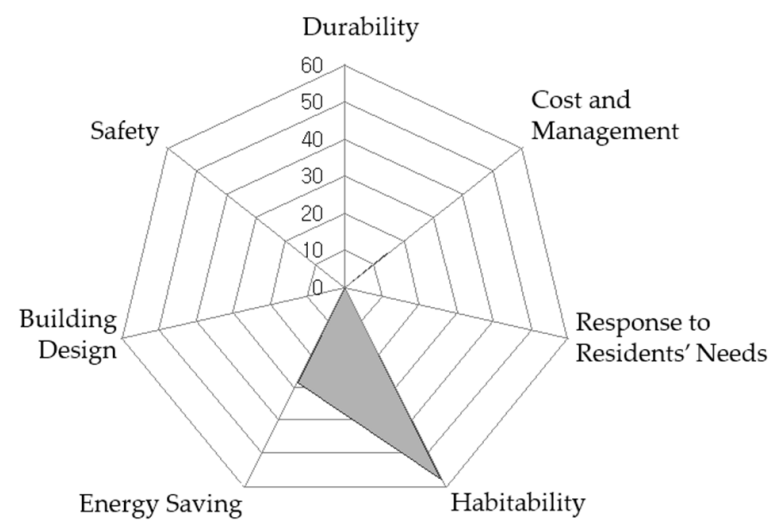

Figure 7. Radar chart of housing quality improvement policy feature in Germany.

As a policy on cost and maintenance under the performance aspect, the Soft Loan for Building Modernization program was studied. This program has been implemented to promote quality improvement of existing housing built in the past, and was being operated as an improvement and maintenance program in the housing market. Detailed design specifications on housing quality were organized through preparation of the building standard law. Particularly in the case of German housing, there were regulations on insulation performance and more regarding windows, ceilings, and 
such of the internal housing space within the German Institute for Standardization Standards (DIN). Moreover, every state established a building standard law, with strict standards on the structural safety of buildings. In addition, it was found that the Barrier Free (BF) policy that has been in operation considered disabled or elderly residents.

For the functional aspect, Germany was encouraging the use of green building materials for housing, and as its exemplary system, the Blue Angel certification system was belonged to it. Relatively many policies on habitability were studied, and policies for green building materials as well as indoor air quality were mostly belonged to functional aspect. This was analyzed as a policy that was raised regarding the environmental friendliness of buildings [49-52].

It was found that no policies for improving housing quality on the aesthetic aspect existed.

\subsection{Policy Status for Housing Quality in Russia}

Table 8 shows Russia's policies for improving housing quality. Under the functional aspect, there was great importance placed on energy saving as shown in Figure 8. Only the RAASN and the KERM Buildings assessed habitability in the performance aspect, and other policies that assessed performance and aesthetic aspects were not examined. Meanwhile, "A New Code on Skyscrapers in Moscow" is a policy for thermal energy efficiency improvement and energy conversation in skyscrapers, and similar policies from other countries were not examined [53,54].

Table 8. Policy status for quality of housing in Russia.

\begin{tabular}{|c|c|c|c|c|c|c|c|c|}
\hline \multirow{3}{*}{ No. } & \multirow{3}{*}{ Policy } & \multicolumn{7}{|c|}{ Housing Quality ${ }^{(1)}$} \\
\hline & & \multicolumn{3}{|c|}{ Performance } & \multicolumn{3}{|c|}{ Function } & \multirow{2}{*}{$\begin{array}{c}\text { Aesthetics } \\
\text { Building } \\
\text { Design }\end{array}$} \\
\hline & & Safety & Durability & Cost ${ }^{(2)}$ & Response $^{(3)}$ & Habitability & $\begin{array}{l}\text { Energy } \\
\text { Saving }\end{array}$ & \\
\hline 1 & $\begin{array}{l}\text { Reduction of } \\
\text { Energy } \\
\text { Consumption }\end{array}$ & & & & & & $\bullet$ & \\
\hline 2 & $\begin{array}{l}\text { A new Code on } \\
\text { Skyscrapers in } \\
\text { Moscow }\end{array}$ & & & & & & $\bullet$ & \\
\hline 3 & $\begin{array}{l}\text { RAASN (Russian } \\
\text { Academy of } \\
\text { Architecture and } \\
\text { Construction } \\
\text { Science) }\end{array}$ & & & & & 0 & $\bullet$ & \\
\hline 4 & KERM Buildings & & & & & 0 & $\bullet$ & \\
\hline 5 & $\begin{array}{l}\text { ASENMCO } \\
\text { (Association of } \\
\text { Engineers for } \\
\text { micro-contamination } \\
\text { Control) }\end{array}$ & & & & & $\bullet$ & & \\
\hline \multirow{2}{*}{$\begin{array}{l}\text { Total } \\
\text { score }\end{array}$} & $\begin{array}{l}\text { Middle category } \\
\text { score }\end{array}$ & - & - & - & - & 3 & 4 & - \\
\hline & $\begin{array}{l}\text { Major category } \\
\text { score }\end{array}$ & & - & & & 7 & & - \\
\hline
\end{tabular}




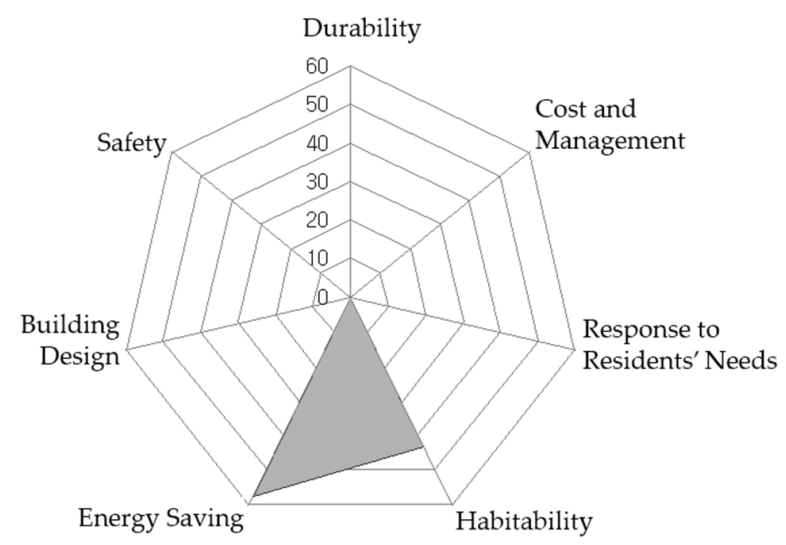

Figure 8. Radar chart of housing quality improvement policy feature in Russia.

\subsection{Policy Status for Housing Quality in Italy}

As shown in Table 9 and Figure 9, Italy had three policies for improving housing quality, all of which were leaning towards energy savings under function. It was found that no policies consider the performance and aesthetic aspects. Meanwhile, RECerT, which is being carried out in many European countries, is a system that grants certificates based on renewable energy output predictions. Certificates received on renewable energy production are exchangeable for market value, and it was found that they could be used for economic profit generation [55-57].

Table 9. Policy status for quality of housing in Italy.

\begin{tabular}{|c|c|c|c|c|c|c|c|c|}
\hline \multirow{3}{*}{ No. } & \multirow{3}{*}{ Policy } & \multicolumn{7}{|c|}{ Housing Quality ${ }^{(1)}$} \\
\hline & & \multicolumn{3}{|c|}{ Performance } & \multicolumn{3}{|c|}{ Function } & \multirow{2}{*}{$\begin{array}{c}\text { Aesthetics } \\
\text { Building } \\
\text { Design }\end{array}$} \\
\hline & & Safety & Durability & $\operatorname{Cost}^{(2)}$ & Response ${ }^{(3)}$ & Habitability & $\begin{array}{l}\text { Energy } \\
\text { Saving }\end{array}$ & \\
\hline 1 & $\begin{array}{l}\text { PV City } \\
\text { Guide-Sustainable } \\
\text { Energy in Buildings }\end{array}$ & & & & & & $\bullet$ & \\
\hline 2 & $\begin{array}{l}\text { RECerT (The } \\
\text { European Renewable } \\
\text { Electricity Certificate } \\
\text { Trading Project) }\end{array}$ & & & & & & • & \\
\hline 3 & $\begin{array}{l}\text { MITRE (Monitoring } \\
\text { and Modelling } \\
\text { Initiative on the } \\
\text { Targets for Renewable } \\
\text { Energy) }\end{array}$ & & & & & & $\bullet$ & \\
\hline \multirow{2}{*}{$\begin{array}{l}\text { Total } \\
\text { score }\end{array}$} & Middle category score & - & - & - & - & - & 3 & - \\
\hline & Major category score & & - & & & 3 & & - \\
\hline
\end{tabular}




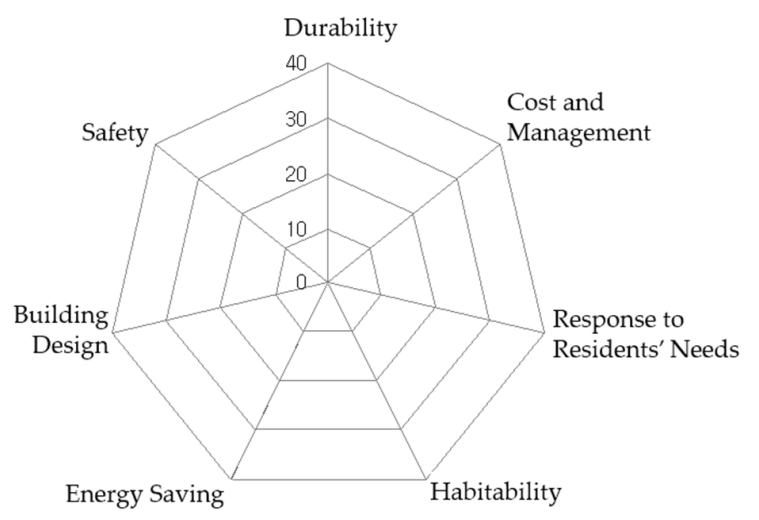

Figure 9. Radar chart of housing quality improvement policy feature in Italy.

\subsection{Policy Status for Housing Quality in France}

Table 10 shows France's policies for improving housing quality. A total of nine policies were examined. There was great importance placed on cost and maintenance under the performance aspect as shown in Figure 10. Particularly, regarding policies regarding cost and maintenance, there was a policy for subsidizing building purchasing costs as well as housing improvement and maintenance costs for low income people, the disabled, and the elderly [58-61].

Table 10. Policy status for quality of housing in France.

\begin{tabular}{|c|c|c|c|c|c|c|c|c|}
\hline \multirow{3}{*}{ No. } & \multirow{3}{*}{ Policy } & \multicolumn{7}{|c|}{ Housing Quality ${ }^{(1)}$} \\
\hline & & \multicolumn{3}{|c|}{ Performance } & \multicolumn{3}{|c|}{ Function } & \multirow{2}{*}{$\begin{array}{c}\text { Aesthetics } \\
\text { Building } \\
\text { Design }\end{array}$} \\
\hline & & Safety & Durability & Cost ${ }^{(2)}$ & Response ${ }^{(3)}$ & Habitability & $\begin{array}{l}\text { Energy } \\
\text { Saving }\end{array}$ & \\
\hline 1 & $\begin{array}{l}\text { QUALITEL (for } \\
\text { residential: } \\
\text { CERQUAL, } \\
\text { CEQUAMI) }\end{array}$ & 0 & $\bigcirc$ & $\bigcirc$ & 0 & 0 & $\bigcirc$ & \\
\hline 2 & $\begin{array}{l}\text { PALULOS (public } \\
\text { rental housing } \\
\text { renewal grant) }\end{array}$ & & & $\bullet$ & & & & \\
\hline 3 & $\begin{array}{l}\text { PAH (owner-occupied } \\
\text { housing improvement } \\
\text { grant) }\end{array}$ & & & $\bullet$ & & & & \\
\hline 4 & $\begin{array}{l}\text { Public housing } \\
\text { construction grant }\end{array}$ & & & • & & & & \\
\hline 5 & $\begin{array}{l}\text { PLAI (households } \\
\text { with income lower } \\
\text { than } 55 \% \text { to } \\
60 \% \text { income) }\end{array}$ & & & $\bullet$ & & & & \\
\hline 6 & $\begin{array}{l}\text { PLI (intermediate loan } \\
\text { for low-cost housing) }\end{array}$ & & & $\bullet$ & & & & \\
\hline 7 & $\begin{array}{l}\text { PAP (housing for sale } \\
\text { loan system) }\end{array}$ & & & $\bullet$ & & & & \\
\hline 8 & $\begin{array}{l}\text { APL (for individual } \\
\text { housing) }\end{array}$ & & & $\bullet$ & O & & & \\
\hline 9 & $\begin{array}{l}\text { PLH (local housing } \\
\text { program) }\end{array}$ & & & & 0 & O & & \\
\hline \multirow{2}{*}{$\begin{array}{l}\text { Total } \\
\text { score }\end{array}$} & Middle category score & 1 & 1 & 8 & 3 & 2 & 1 & - \\
\hline & Major category score & & 10 & & & 6 & & - \\
\hline
\end{tabular}




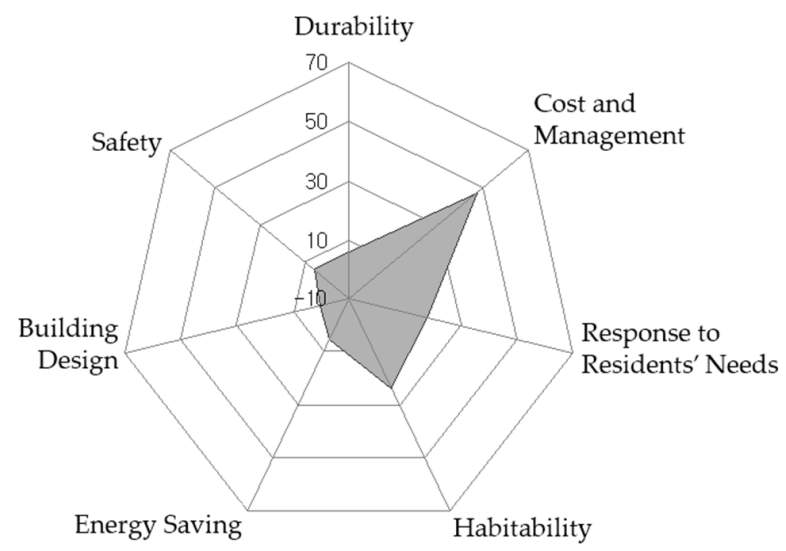

Figure 10. Radar chart of housing quality improvement policy feature in France.

\subsection{Policy Status for Housing Quality in Spain}

As Table 11 shows, Spain had three policies for improving housing quality. All of them regard energy saving under the functional aspect as shown in Figure 11. RECerT and the PV City Guide are the integrated systems that are being carried out not only in Spain, but also in other European countries $[62,63]$.

Table 11. Policy status for quality of housing in Spain.

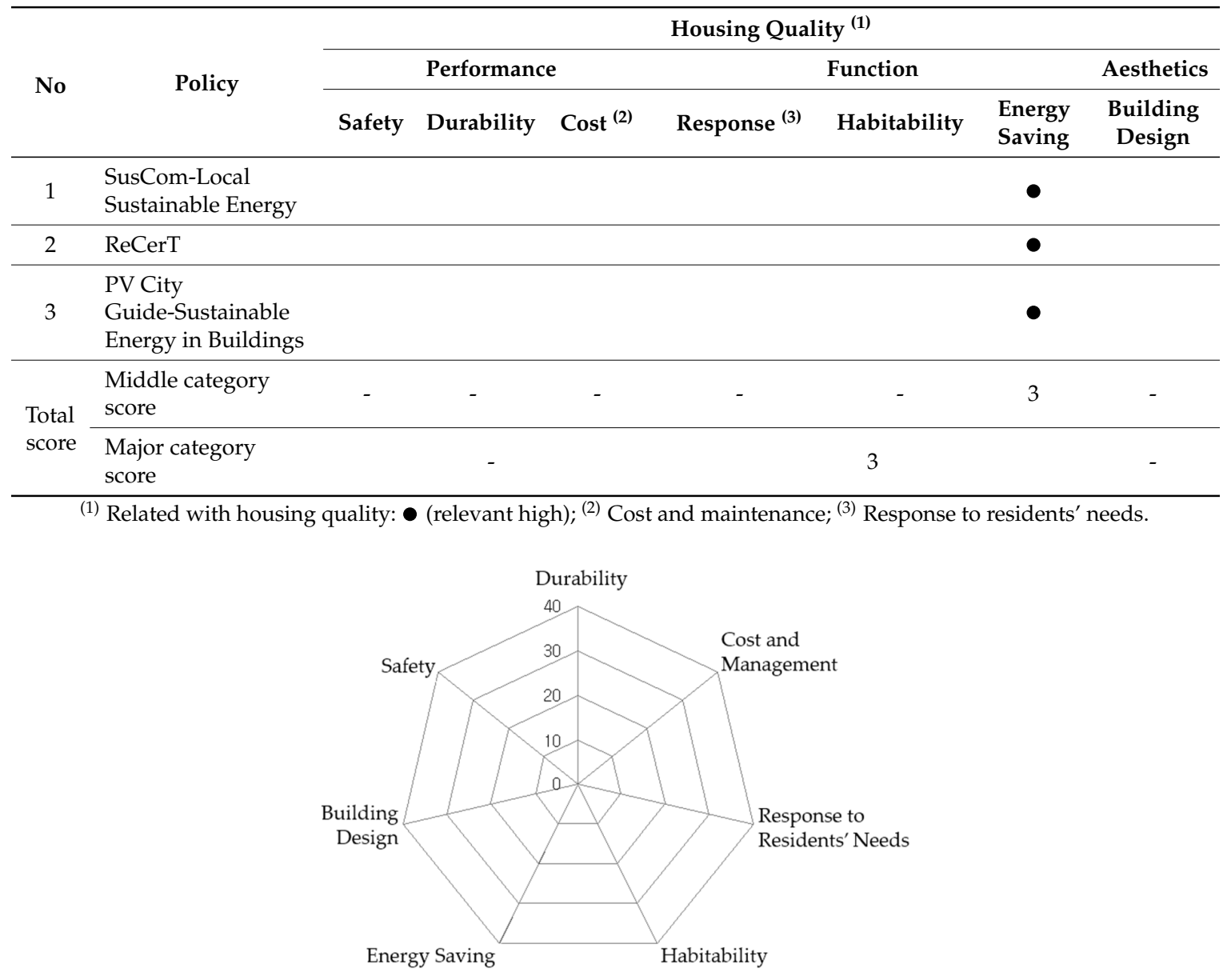

Figure 11. Radar chart of housing quality improvement policy feature in Spain. 


\section{Overall Analysis}

\subsection{Housing Quality Policy Unconstructed In South Korea}

As shown in Figure 12, in case of Japan's "Certification of model crime-resistant apartment buildings" policy for constructing the safe housing and urban environment, performance of security technology was developed by consideration of crime prevention. In the aspect of regeneration of housing in superior condition, "BL (Better living) certification standards" policy of Japan set high value on performance of high durable structural materials and finishing materials. In addition, "CENTURY housing system" policy of Japan places emphasis on the longevity of Buildings. In addition, also Japan emphasis on the interior finishing materials and interior items, so that "Safe Interior Material Certification System", "Standard Value mark" policy are now on operation. In case of Russia, skyscraper policy such as "A new Code on Skyscrapers in Moscow" is considered to be critical in the aspect of establishment of skyscraper's quality assessment items, which is about thermal energy improvement. Regarding to the $\mathrm{LCCO}_{2}$ assessment, CASBEE already reflected the evaluation of building's $\mathrm{LCCO}_{2}$. In case of U.S.'s policy such as LEED, cost and maintenance of building lifecycle and the IAQ (Indoors Air Quality) is considered to be important.

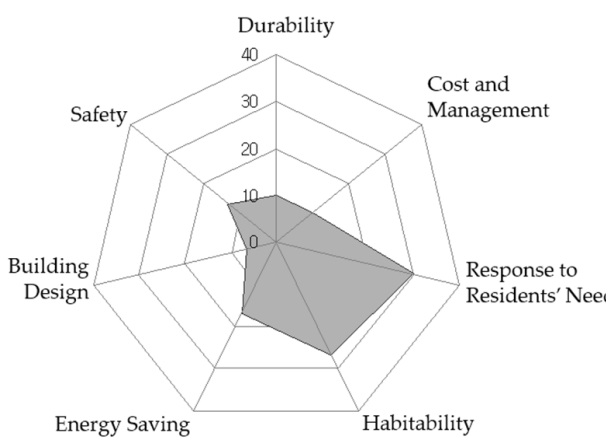

(a)

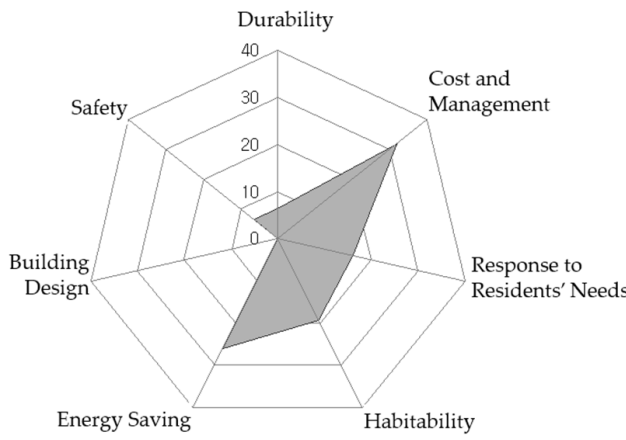

(c)

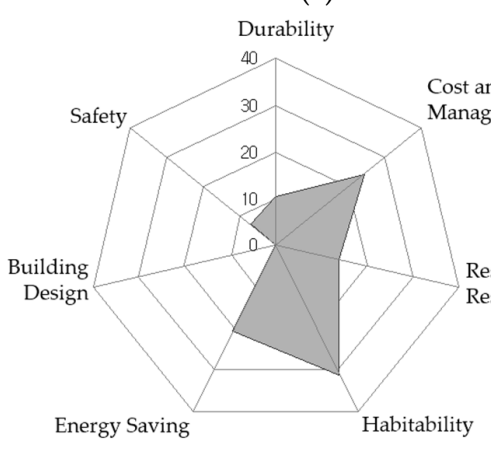

(e)

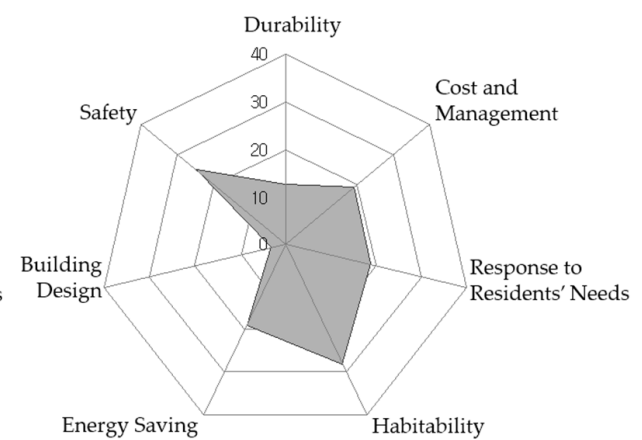

(b)

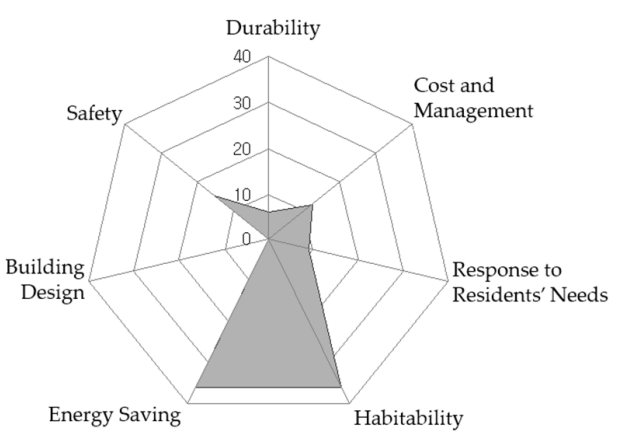

(d)

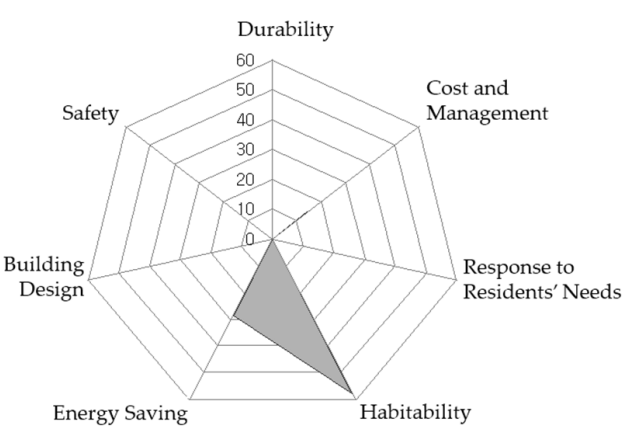

(f)

Figure 12. Cont. 


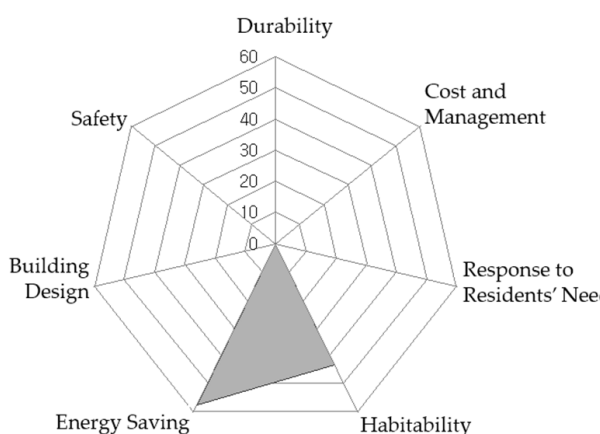

(g)

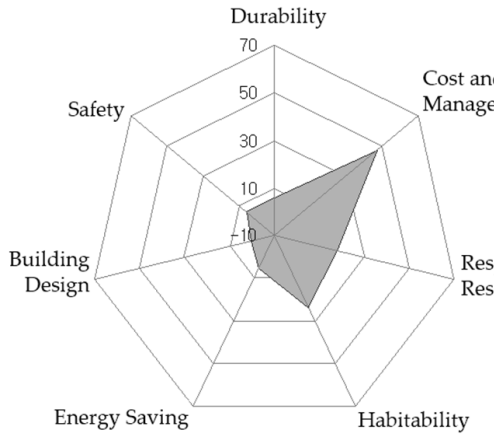

(i)

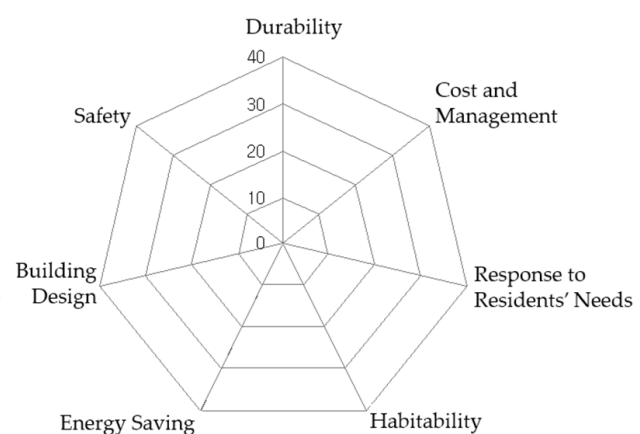

(h)

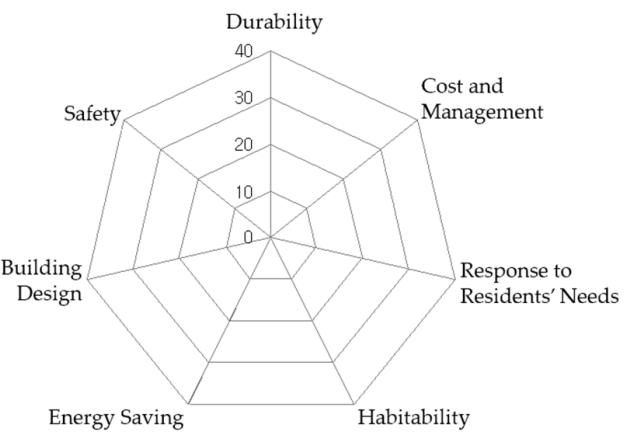

(j)

Figure 12. Radar chart of housing quality improvement policy feature in all target nations. (a) South Korea; (b) Japan; (c) US; (d) Canada; (e) UK; (f) Germany; (g) Russia; (h) Italy; (i) France; (j) Spain.

After analyzing foreign policies on improving housing quality that were judged as not adopted in South Korea, a total of seven were examined, as Table 12 shows.

Table 12. Quality of housing policy unconstructed In South Korea.

\begin{tabular}{|c|c|c|c|c|c|c|c|c|c|}
\hline \multirow{3}{*}{ No } & \multirow{3}{*}{ Policy } & \multirow{3}{*}{$\begin{array}{l}\text { Housing Quality }{ }^{(1)} \\
\text { Performance Safety }\end{array}$} & \multicolumn{7}{|c|}{ Housing Quality ${ }^{(1)}$} \\
\hline & & & \multicolumn{3}{|c|}{ Performance } & \multicolumn{3}{|c|}{ Function } & \multirow{2}{*}{$\begin{array}{c}\text { Aesthetics } \\
\text { Building } \\
\text { Design }\end{array}$} \\
\hline & & & Safety & Durability & $\operatorname{Cost}^{(2)}$ & Response $^{(3)}$ & Habitability & $\begin{array}{l}\text { Energy } \\
\text { Saving }\end{array}$ & \\
\hline 1 & Russia & $\begin{array}{l}\text { A new Code on } \\
\text { Skyscrapers in } \\
\text { Moscow }\end{array}$ & & & & & & $\bullet$ & \\
\hline 2 & $\begin{array}{l}\text { Italy, } \\
\text { Spain }\end{array}$ & RECerT & & & & & & $\bullet$ & \\
\hline 3 & \multirow{5}{*}{ Japan } & $\begin{array}{l}\text { Certification of } \\
\text { model } \\
\text { crime-resistant } \\
\text { apartment buildings }\end{array}$ & $\bullet$ & & & & & & \\
\hline 4 & & $\begin{array}{l}\text { CENTURY housing } \\
\text { system }\end{array}$ & $\bigcirc$ & $\bigcirc$ & $\bigcirc$ & 0 & $\bigcirc$ & & \\
\hline 5 & & $\begin{array}{l}\text { Safe Interior Material } \\
\text { Certification System }\end{array}$ & & & & & $\bullet$ & & \\
\hline 6 & & Standard Value mark & & & & & $\bullet$ & & \\
\hline 7 & & $\begin{array}{l}\text { High-rise Building } \\
\text { Performance } \\
\text { Evaluation System }\end{array}$ & $\bullet$ & & & & & & \\
\hline \multirow{2}{*}{\multicolumn{2}{|c|}{ Total score }} & $\begin{array}{l}\text { Middle category } \\
\text { score }\end{array}$ & 3 & 1 & 1 & 1 & 3 & 2 & - \\
\hline & & Major category score & & 5 & & & 6 & & - \\
\hline
\end{tabular}

(1) Related with housing quality: • (relevant high), $\bigcirc$ (normal); ${ }^{(2)}$ Cost and maintenance; ${ }^{(3)}$ Response to residents' needs. 
As a policy for energy saving, Russia's A New Code on Skyscrapers in Moscow was examined. This policy was developed for global environmental load reduction, maintenance cost reduction, and improvement of living environment for residents through efficient energy usage in skyscrapers via legal regulation of thermal energy efficiency in skyscrapers.

In addition, Italy's RECerT, which is relevant to saving energy, was found to be a system made in to grant economic benefits to buildings or institutions that produce renewable energy. It was also analyzed as generating economic benefits because when it grants certificates after predicting the renewable energy output of the building, these certificates retain their market value. Currently, RECerT was found to be applied in European countries such as Austria, Denmark, Finland, France, Germany, Greece, Norway, Hungary, Spain, Sweden, and the UK.

Japan's policies such as the Model Anticrime Mansion Certification System, the High-rise Building Performance Certification System, the Century Housing System, the Safe Interior Material Certification System, and Standard Value mark were found to be the policies that do not exist in South Korea. The Model Anticrime Mansion Certification System, which is about safety improvement policy under performance, promotes the supply of housing with excellent crime proofing and certifies crime prevention. It establishes the design specifications on housing, develops building components with excellent anti-crime performance, and announces the products that pass the anti-crime performance test. The High-rise Building Performance Certification System was examined as a policy for the structural safety of skyscrapers. In addition, the Century Housing System was being operated as a total system certification scheme to offer housing that can maintain a comfortable lifestyle in the long term through increasing the functional durability of housing in design, production, and maintenance. Regarding policies for improving habitability under function, there was the Safe Interior Material Certification System and Standard Value mark. These were similar to South Korea's Healthy Building Material certification system, but there was a difference in that they were only relevant to interior materials and wallpaper.

\subsection{Housing Quality Policy Similar to South Korea}

Policies for improving housing quality that are similar to those of South Korea were categorized into the housing improvement and maintenance subsidy system, the energy saving related system, the housing performance rating system, and the green building certification system.

The US housing improvement and maintenance subsidy system is being operated via integration into the CDBG. Through the CDBG, the US government is providing loans for low income people and the owners of rental housing via offering public funds with low interest rates. Meanwhile, the Special Housing Maintenance and Improvement Support System offers loans for housing improvement costs for those living below the poverty line, the elderly, and the disabled, with each state running diverse maintenance and improvement programs.

In the case of the UK, intensive improvement and maintenance was being carried out through providing subsidies or loans. Deteriorated areas were mainly selected as improvement areas rather than detached housing. There was also a policy for giving income tax exemptions on some parts of the building cost.

Meanwhile, in terms of housing improvement and maintenance subsidization systems, in 2001 South Korea introduced the National Housing Fund's loan program for deteriorated housing, and the Residential Insulation Installation loan program through the Rational Energy Utilization fund. On the other hand, for the case of systems related to loans for deteriorated housing, Germany had adopted a preferential finance and taxation system on small, deteriorated, detached housing aged 20 years or more to promote housing improvement and maintenance.

Among the environmentally advanced countries of the world such as energy-efficient green European countries, policies on energy saving in buildings have been enacted. Examples of such policies are the US's HERS, Energy Star Home/Building Program, EEM, and more; the UK's The Low Carbon Building Program; Japan's Building Environment Efficiency Labeling Program, and the New 
Energy Standard Housing Assessment System; and 16-18 European countries including Italy, the UK, Germany, and Spain were applying the RECerT and the PV City Guide. South Korea is also making the apartment performance rating system mandatory to allow consumers to know about housing performance before moving in. The system works by assigning a rating of $1-4$ on the housing with 5 categories such as noise, structure, environment, living conditions, and fire safety.

In foreign countries, there are various types of building energy saving systems in place, and there are also assessments in energy efficiency for not only newly constructed buildings, but also existing buildings, along with improvements and maintenance subsidization systems for energy saving housing with high-efficiency facility costs on buildings with low energy efficiency.

\section{Proposal}

As shown in Figure 13, this study presents a policy direction proposal diagram from the perspective of South Korea's housing policies based on the results of analyzing policies for improving housing quality in South Korea and other major countries that are selected.

Broadly, five types of policy directions for improving housing quality based on the performance, function, and aesthetic categories were proposed.

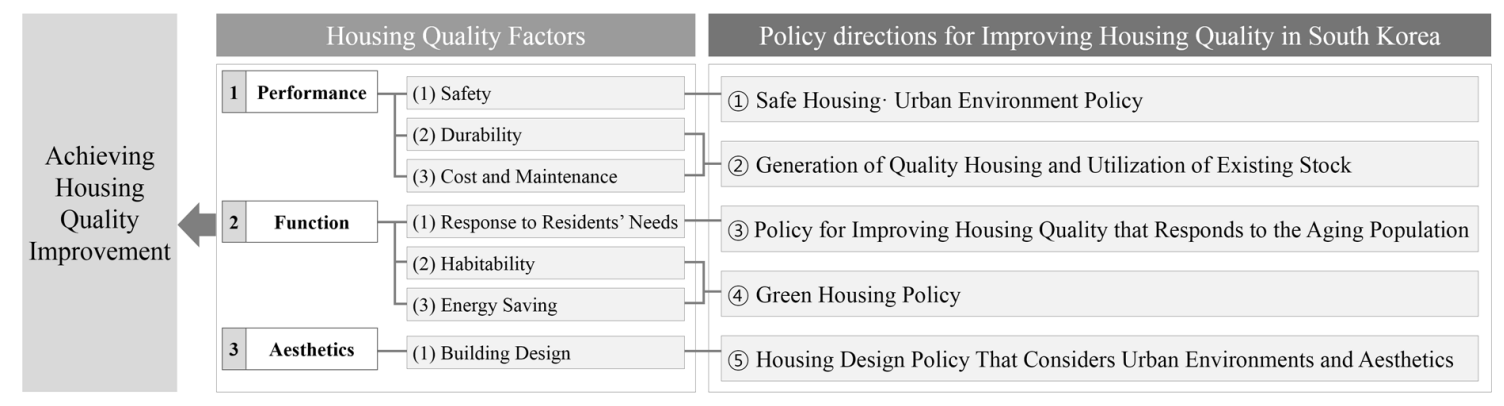

Figure 13. Overview of Policy direction suggestions for improving housing quality.

In the performance aspect, policy directions for safe housing and urban environment that consider safety were proposed. In addition, policy direction for building quality housing and utilizing existing stock while taking durability, cost, and maintenance into consideration were proposed.

In the functional aspect, as South Korea is becoming an aging society, policy direction for improving housing quality that respond to an elderly society with consideration for responding to residents' needs were proposed, and policy directions for green buildings were proposed.

Finally, in the aesthetic aspect, policy directions for housing designs that consider urban environment aesthetics to vitalize urban dwellers and aim for unique city models were proposed.

\subsection{Performance Aspects}

\subsubsection{Policy for Safe Housing and Urban Environment}

From the aspect of performance in housing, the safe housing environment and urban environment must be established. Particularly, to prevent fires in deteriorated housing, there should be technical policies that can assure the safety of residents in advancing fire control and prevention performances, providing speedy recovery on various natural disasters, and securing housing. In addition, to relieve residents' uneasiness about their living environment improvements, technical policies that can improve anti-crime performance must be developed.

\subsubsection{Regeneration of Quality Housing Stock and the Utilization of Existing Housing Stock}

For the longevity of existing housing, financial support systems must be established to invigorate reform and rebuilding. An institutional basis must be established by providing data on reform 
business operators among other things. Additionally, like Japan's Better-Living system, there must be the establishment of policies that can support the performance assessment of highly durable structural materials as well as finishing materials, and can lead to the development of efficient maintenance systems.

In addition, for the development of a sustainable city that can adjust to increases in population like Japan's High-rise Building Performance Evaluation System, the assessment standards on high-rise apartments must be established for improving housing quality and related elements. Policies for the development of energy performance assessment systems must also be established.

\subsection{Functional Aspects}

\subsubsection{Policy for Improving Housing Quality that is Responsive to an Aging Society}

In the functional aspect of housing, for the housing owned by the elderly who suffer from reductions in physical function, policies must be developed that can promote BF design by giving preferential mortgage rates, standardizing BF design during the construction of public rental housing, and the provision of rental housing with BF designs. Meanwhile, to assure elderly residency, a system that can relieve anxiety must be established for them through a housing registration system that does not exclude them from moving in. In addition, there must be an introduction of an open notification system for housing information. Even further, in order for the elderly to be able to continue living in their housing with peace of mind, there must be an organization for a lifetime building lease system. Moreover, policies that can set the foundation for silver houses, which for the elderly must be established, such as providing assistance services for everyday life.

\subsubsection{Green Housing Policy}

In the functional aspect of housing, there is a need for policies that can promote the development of advanced technology for energy conservation without lowering comfort, which is the most important criterion of habitability. There must be an establishment of policies that can support the development of technology applicable to apartments such as the energy conversion system, and policies that support the development of technology that can allow consumers to assess and control energy usage must be established as well.

When considering energy savings, there must be an examination introducing measures for housings such as Japan's CASBEE reflecting $\mathrm{LCCO}_{2}$ 's calculation results under the environmental load assessment category. South Korea also needs to introduce a system that develops monitoring technology for $\mathrm{LCCO}_{2}$ emissions in housings and regulates such emissions.

Just as Japan enforces the Safe Interior Material Certification System and Standard Value mark considering the wallpaper product standard, South Korea must also develop the technologies that improve indoor air quality for enhancing comfort in housing, and establish policies that can support those technologies. Particularly, there is an urgent need for a green technical housing policy for the development of an index of quantified standards on quality of life adapted to South Korea.

\subsection{Housing Design Policy with Consideration of the Urban Environment and Aesthetics}

For the reduction of urban heat island effects and the improvement of dwelling satisfaction, there must be an establishment of policies that can provide a foundation for the development of energy-efficient housings that applies efficient natural lighting, natural ventilation systems, and biotopes. Additionally, there must be an establishment of a policy base that can increase urban vitality by satisfying various demands of residents at once (such as floor plan, lighting, and access to sunlight). In order to increase urban aesthetics individuality, there should be policies for exterior design guidelines in housing that form harmony with the city. 


\section{Discussion}

In this paper, there is intention of contribution stimulating having a priority position in housing improvement by suggesting policy direction to improve the housing quality.

The main characteristic of construction industry is extensive project scale in the point of view such as construction expenses, construction period, etc. In addition, there are various factors to satisfy strictly such as safety, barrier free design, etc. Therefore, total directional foundation of building policy must be established. In order to promote construction industry in positive way, abundant research regarding to the primitive policy base of construction industry is a prerequisite to sustainable future society.

In this section, we discuss this study's breaking points and the directions for further research.

The housing quality was categorized into performance, function, and aesthetics, and policy proposals were made for the mid to long term improvement of housing quality in South Korea based on the analysis of the policy status of various countries selected for the study. By proposing policy directions on the development direction of performance, function, and the aesthetic aspects of policy proposals on South Korea's improvement in housing quality, the major aspects of the subject were handled, and therefore had difficulty proposing concrete policies that take into account the real conditions of the country. In addition, because policy proposals change along with changes in policy standpoint via periodic changes in South Korea's industrial structure and economic management methods, continuous research related to housing quality policy proposals from the academic community are demanded. As later research on policy proposals is carried out, there is a need for phased research that can propose multilaterally, and specifically, policies that match the country's situation.

Accordingly, by amending the weak points of South Korea's current policies that improve housing quality and by maximizing the strong points, there can be an establishment of a basis for quantitative assessment of South Korea's green housing performance, thereby strategically satisfying the rising social demand for better housing quality.

\section{Conclusions}

This study attempts to propose policy directions and systematic reforms improving South Korea's housing quality based on our analysis of various countries' policies for improving housing quality. The conclusions are as follows.

(1) We categorized housing quality as having three aspects: performance, function, and aesthetics. Policies on improving housing quality in Japan, the US, Canada, the UK, and Germany, and proposed policy directions for improving housing quality in South Korea were analyzed.

(2) In the performance aspect, we proposed policy directions in the direction of establishing an urban environment through forming safe housing environments among deteriorated housing via improving crime prevention performance, and maintaining urban facilities for the purpose of forming communities among residents. Additionally, we proposed policy directions in the direction of enabling the regeneration of quality housing and the recycling of existing housing.

(3) In the functional aspect, as South Korea is rapidly becoming an aging society, we proposed policy directions such as Barrier Free access related to improving housing quality for the elderly, welfare reform, and a residency guarantee system for the elderly. With consideration on habitability and energy savings under the functional aspects, we also proposed policy directions related to providing green housing with low energy such as assessing and managing energy usage while maintaining the comfort of the inhabitants, improving indoor environmental comfort, and monitoring $\mathrm{CO}_{2}$ emissions.

(4) In terms of aesthetic aspects, we proposed policy directions that reduce urban heat island effects while at the same time satisfying the demands of residents. In addition, to promote housing 
aesthetics individuality that form harmony with the city, we proposed policy directions such as the design policy that considers the aesthetics of urban environments.

Acknowledgments: This research was supported by Basic Science Research Program through the National Research Foundation of Korea (NRF) funded by the Ministry of Science, ICT \& Future Planning (No. 2015R1A5A1037548) and the National Research Foundation of Korea (NRF) grant funded by the Korea government (MSIP) (No. 20110028794).

Author Contributions: All authors contributed substantially to all aspects of this article.

Conflicts of Interest: The authors declare no conflict of interest.

\section{References}

1. ChosunBiz. High-Rise Complex Housings. Available online: http://biz.chosun.com/site/data/html_dir/ 2015/05/31/2015053100914.html (accessed on 2 June 2015). (In Korean)

2. HonggyunPark. Accommodation Capacity for Housing. Available online: http://hkpark.netholdings.co.kr/ web/manual/default/manual_view.asp?menu_id=101181\&id=1033 (accessed on 2 June 2015). (In Korean)

3. Statistics Korea. Housing Supply Ratio. Available online: http://kosis.kr/nsportalStats/nsportalStats_ 0102Body.jsp;jsessionid=NpecDSIxzcggCtEYalKiFzllybyfeMIK7HgLGbnfuk8ZiiVqQbjnQC1ZwCYqikuO. STAT_WAS1_servlet_engine1?menuId=7\&NUM=280 (accessed on 2 June 2015). (In Korean)

4. Real-estate 114. Nationwide Housing Sales Volume. Available online: http:/ /www.r114.com/ (accessed on 2 June 2015). (In Korean)

5. Radio Free Asia. High-Rise Housing's Problems. Available online: http://www.rfa.org/korean/weekly_ program/environment/high_rise-06102010114908.html (accessed on 2 June 2015). (In Korean)

6. Ministry of Environment. A Survey of Indoor Air Quality in New Constructed Housings. Available online: http://webcache.googleusercontent.com/search?q=cache:SS-AG_mmCvUJ:www.me.go.kr/home/file/ readDownloadFile.do\%3Bjsessionid\%3DZ2T7BURfLnJA42Ins3zSJthPhNrM5HUx2or1i4VzMyKxkx252K1B1 biLgo4jtlYX.meweb2vhost_servlet_engine1\%3FfileId\%3D26248\%26fileSeq\%3D1+\&cd=1\&hl=ko\&ct=clnk\&gl $=\mathrm{kr}$ (accessed on 2 June 2015). (In Korean)

7. Ministry of Land, Infrastructure and Transport (MOLIT). Framework Plan for Housing Research and Development. Available online: http://www.google.co.kr/url?sa=t\&rct=j\&q=\&esrc=s\&source= web\&cd=1\&ved=0ahUKEwjm3rWF3LLMAhWi2qYKHRWdCowQFgggMAA\&url=http\%3A\%2F\%2Fwww. prism.go.kr\%2Fhomepage\%2FresearchCommon\%2FdownloadResearchAttachFile.do\%3Bjsessionid\%3D1A0 11D3B0A4380F6576F7216CA06DA3A.node02\%3Fwork_key\%3D001\%26file_type\%3DCPR\%26seq_no\%3D0 01\%26pdf_conv_yn\%3DN\%26research_id\%3D1613000-201300055\&usg=AFQjCNH49UKTCpKYNSq09Avxc MvaFsAuNg\&sig2=QVdrMwo04-EATgVPyk3iyQ\&bvm=bv.120853415,d.dGY\&cad=rjt (accessed on 2 June 2015). (In Korean)

8. Korea Institute of Civil Engineering and Building Technology (KICT). The Final Report of Housing RED Basic Stage Plan; KICT: Seoul, South Korea, 2014. (In Korean)

9. Ministry of Land, Infrastructure and Transport (MOLIT). The Final Report of Roadmap for National GHG Reduction Goals; MOLIT: Seoul, South Korea, 2014.

10. Statistics Korea. Available online: http://www.index.go.kr/potal/main/EachDtlPageDetail.do?idx_cd= 1227 (accessed on 11 November 2015). (In Korean)

11. Korea Economics. Available online: http://land.hankyung.com/ (accessed on 15 November 2015). (In Korean)

12. Green Standard for Energy and Environmental Design (G-SEED). Available online: http://www.g-seed.or.kr (accessed on 11 June 2015). (In Korean)

13. Korea Infrastructure Safety \& Technology Corporation (KISTEC). Available online: https://www.kistec.or. $\mathrm{kr} / \mathrm{kistec} /$ business /business0701.asp?flashActive $=010701$ (accessed on 18 June 2015). (In Korean)

14. Shin, S.W.; Tae, S.H.; Woo, J.H.; Roh, S.J. The development of environmental load evaluation system of a standard Korean apartment house. Renew. Sustain. Energy Rev. 2011, 15, 1239-1249.

15. Korea Environmental Industry \& Technology Institute. Available online: http://www.edp.or.kr/carbon (accessed on 7 June 2015). (In Korean)

16. Ministry of Land, Infrastructure, Transport and Tourism (MLIT). Available online: http://www.mlit.go.jp (accessed on 15 January 2016). (In Japanese) 
17. Roh, S.J.; Tae, S.H.; Shin, S.W. Development of building materials embodied greenhouse gases assessment criteria and system (BEGAS) in the newly revised Korea Green Building Certification System (G-SEED). Renew. Sustain. Energy Rev. 2014, 35, 410-421.

18. Tae, S.H.; Shin, S.W.; Woo, J.H.; Roh, S.J. The development of apartment house life cycle $\mathrm{CO}_{2}$ simple assessment system using standard apartment houses of South Korea. Renew. Sustain. Energy Rev. 2011, 15, 1454-1467.

19. Jang, M.H.; Hong, T.H.; Ji, C.Y. Hybrid LCA model for assessing the embodied environmental impacts of buildings in South Korea. Environ. Impact Assess. Rev. 2015, 50, 143-145.

20. Interior Safety Material (ISM). Available online: http://www.wacoa.jp/ism/index.html (accessed on 18 December 2015). (In Japanese)

21. Center for Better Living (CBL). BL (Better Living) Labeling System. Available online: http://www.cbl.or.jp/ english/1.html (accessed on 13 December 2015). (In Japanese)

22. Institute for Building Environment and Energy Conservation (IBEC). Available online: http://www.ibec.or. jp/nintei/hyouji/gaiyou.html (accessed on 10 December 2015). (In Japanese)

23. Buildernet. Available online: http://www.builder-net.com/service/default.aspx (accessed on 13 December 2015). (In Japanese)

24. Comprehensive Assessment System for Built Environment Efficiency (CASBEE). Available online: http:/ / www.ibec.or.jp/CASBEE/english/index.htm (accessed on 21 November 2015).

25. Miljana, H.; Paul, F. Comparative review of existing certification programs and performance assessment tools for residential buildings. Archit. Sci. Rev. 2005, 48, 69-80.

26. Seoul Metropolitan Government. Available online: http://www.seoul.go.kr/main/index.html (accessed on 19 December 2015). (In Korean)

27. U.S. Department of Housing and Urban Development. Available online: http://www.hud.gov (accessed on 19 December 2015).

28. California Department of Housing and Community Development. Available online: http://www.hcd.ca.gov (accessed on 19 December 2015).

29. Federal Housing Administration (FHA). Available online: http://en.wikipedia.org/wiki/Federal_Housing Administration (accessed on 19 December 2015).

30. Danter Company. Available online: http://www.danter.com/taxcredit/about.htm (accessed on 19 December 2015).

31. USGBC. Guide to LEED Certification. Available online: http://www.usgbc.org/cert-guide (accessed on 19 December 2015).

32. Scofield, J.H. Efficacy of LEED-certification in reducing energy consumption and greenhouse gas emission for large New York City office buildings. Energy Build. 2013, 67, 517-524.

33. Yair, S.; Rokia, R. Variations in results of building energy simulation tools, and their impact on BREEAM and LEED ratings: A case study. Energy Build. 2013, 62, 350-359.

34. Korea Research Institute for Human Settlements (KRIHS). Linkage system of the city of Boston: New York river development restrictions, Tappan zee bridge. Auric 1986, 56, 8-11. (In Korean)

35. Atlantic Home Warranty Provider. Available online: http://www.ahwp.org/about.html (accessed on 20 December 2015).

36. The Alberta New Home Warranty Program. Available online: http://www.anhwp.com (accessed on 20 December 2015).

37. The Natural Resources Canada. CanmetENERGY. Available online: http://www.sbc.nrcan.gc.ca/buildings / idp_e.asp (accessed on 20 December 2015).

38. Net-Zero Energy Home (NZEH) Coalition. Available online: http://www.buildup.eu/en/category/freeauthors-tags/net-zero-energy-home-nzeh-coalition (accessed on 20 December 2015).

39. The Natural Resources Canada. R-2000 Net Zero Energy Pilot. Available online: http:/ /www.nrcan.gc.ca/ energy/efficiency/housing/new-homes/5085 (accessed on 20 December 2015).

40. Korea Housing Institute (KHI). A study on the introduction assurance system for housing quality improvement. Korea Hous. Inst. 2000, 2, 134-138. (In Korean)

41. Surrey Heath Borough Council. Housing. Available online: http://www.surreyheath.gov.uk/Housing (accessed on 20 December 2015). 
42. The Grants by Local Housing Authorities (Eligible Expense Limits) Order 1988. Available online: http:/ /www.legislation.gov.uk/uksi/1988/1263/contents/made (accessed on 20 December 2015).

43. Housing Improvement in Scotland: A Scoping Paper. Available online: http://www.gov.scot/Resource/ Doc/1035/0015169.pdf (accessed on 20 December 2015).

44. BREEAM UK New Construction. Available online: http://www.breeam.com/index.jsp (accessed on 21 December 2015).

45. BREEAM. Assessor Guidance Note GN08. Available online: https://www.iesve.com/software/impact/ breeam-guidance-note-8-impact.pdf (accessed on 21 December 2015).

46. Koo, S.H. Eco-Friendly Building Certification System of BRE; Korea Green Building Council: Seoul, South Korea, 2012; Volume 13, pp. 62-68. (In Korean)

47. Lee, W.L.; Burnett, J. Benchmarking energy use assessment of HK-BEAM, BREEAM and LEED. Build. Environ. 2008, 43, 1882-1891. [CrossRef]

48. Tiina, N.; Irene, L.; Laura, T. Comparison of housing market sustainability in European countries based on multiple criteria assessment. Land Use Policy 2015, 42, 642-651.

49. Indoor Air Diagnostics-Environmental Consultants. Available online: http://www.iaqinfo.com/ (accessed on 21 December 2015).

50. Construction and PEFC Certified Timber. Available online: http://www.pefc.org/resources/brochures / architects-and-construction/1505-construction-and-pefc-certified-timber (accessed on 21 December 2015).

51. Passive House Institute. Available online: http://www.passiv.de (accessed on 22 December 2015). (In German)

52. Anastasia, K.; Natalia, P.; Julia, Z.; Ksenia, R. Research possibilities for studying the indicators of quality of life of indigenous peoples of the North (based on the study of indigenous peoples of the North of Russia). Life Sci. J. 2014, 11, 593-600.

53. Association of Engineers for Microcontamination Control (ASENMCO). Available online: http:/ / www.asenmco.info/ (accessed on 22 December 2015).

54. S2C2 for Provision of Clean Manufacturing and Product Cleanliness. Available online: http://www.s2c2.co. uk/index.php?option=com_content\&view=article\&id=47:about-us\&catid=34:general\&Itemid=74 (accessed on 22 December 2015).

55. PV City Guide. Available online: http://pvcityguide.energyprojects.net/ (accessed on 22 December 2015).

56. ManagEnergy. Available online: http://managenergy.net/about/policy\#.VrKqy8tf19A (accessed on 22 December 2015).

57. MITRE. Meeting the Targets and Putting Renewables to Work. Available online: http:/ / mitre.energyprojects. net (accessed on 22 December 2015).

58. Fougère, D.; Kramarz, F.; Rathelot, R.; Safi, M. Social housing and location choices of immigrants in France. Int. J. Manpow. 2013, 34, 56-69.

59. Korea Appraisal Board. A Study on Comparing Green Building Certification System in domestic and overseas; Real Estate Focus: Seoul, South Korea, 2012; Volume 51. (In Korean)

60. Korea Housing Institute (KHI). A study on the Home Warranty System; Korea Housing Institute (KHI): Seoul, South Korea, 2000; Volume 5. (In Korean)

61. Embassy of the Republic of Korea in France. The Final Report of French Public Housing; Embassy of the Republic of Korea in France: Seoul, South Korea. (In Korean)

62. SUSCOM. Available online: http://suscom.energyprojects.net/ (accessed on 22 December 2015).

63. ManagEnergy. Saving Energy in Residential Housing, Spain. Available online: http://managenergy.net/ resources/718\#.VyMGlctf2mQ (accessed on 22 December 2015).

(c) 2016 by the authors; licensee MDPI, Basel, Switzerland. This article is an open access article distributed under the terms and conditions of the Creative Commons Attribution (CC-BY) license (http://creativecommons.org/licenses/by/4.0/). 